\title{
Estimates for the Aerodynamic Coefficients of Ringsail and Disk-Gap-Band Parachutes Operating on Mars*
}

\author{
Juan R. Cruz ${ }^{1}$ and Miranda L. Snyder ${ }^{2}$ \\ NASA Langley Research Center, Hampton, Virginia, 23681
}

\begin{abstract}
Models are presented for the aerodynamic coefficients of Supersonic Ringsail and Disk-Gap-Band parachutes as functions of total porosity, $\lambda_{T}$, Mach number, $M$, and total angle of attack, $\alpha_{T}$ (when necessary). The source aerodynamic coefficients data used for creating these models were obtained from a wind tunnel test of subscale parachutes. In this wind tunnel test, subscale parachutes of both parachute types were fabricated from two different fabrics with very different permeabilities. By varying the fabric permeability, while maintaining the parachute geometry constant, it was possible to vary $\lambda_{T}$. The fabric permeability test data necessary for the calculation of $\lambda_{T}$ were obtained from samples of the same fabrics used to fabricate the subscale parachutes. Although the models for the aerodynamic coefficients are simple polynomial functions of $\lambda_{T}$ and $M$, they are capable of producing good reproductions of the source data. The $\left(\lambda_{T}, M\right)$ domains over which these models are applicable are clearly defined. The models are applicable to flight operations on Mars.
\end{abstract}

\section{Nomenclature}

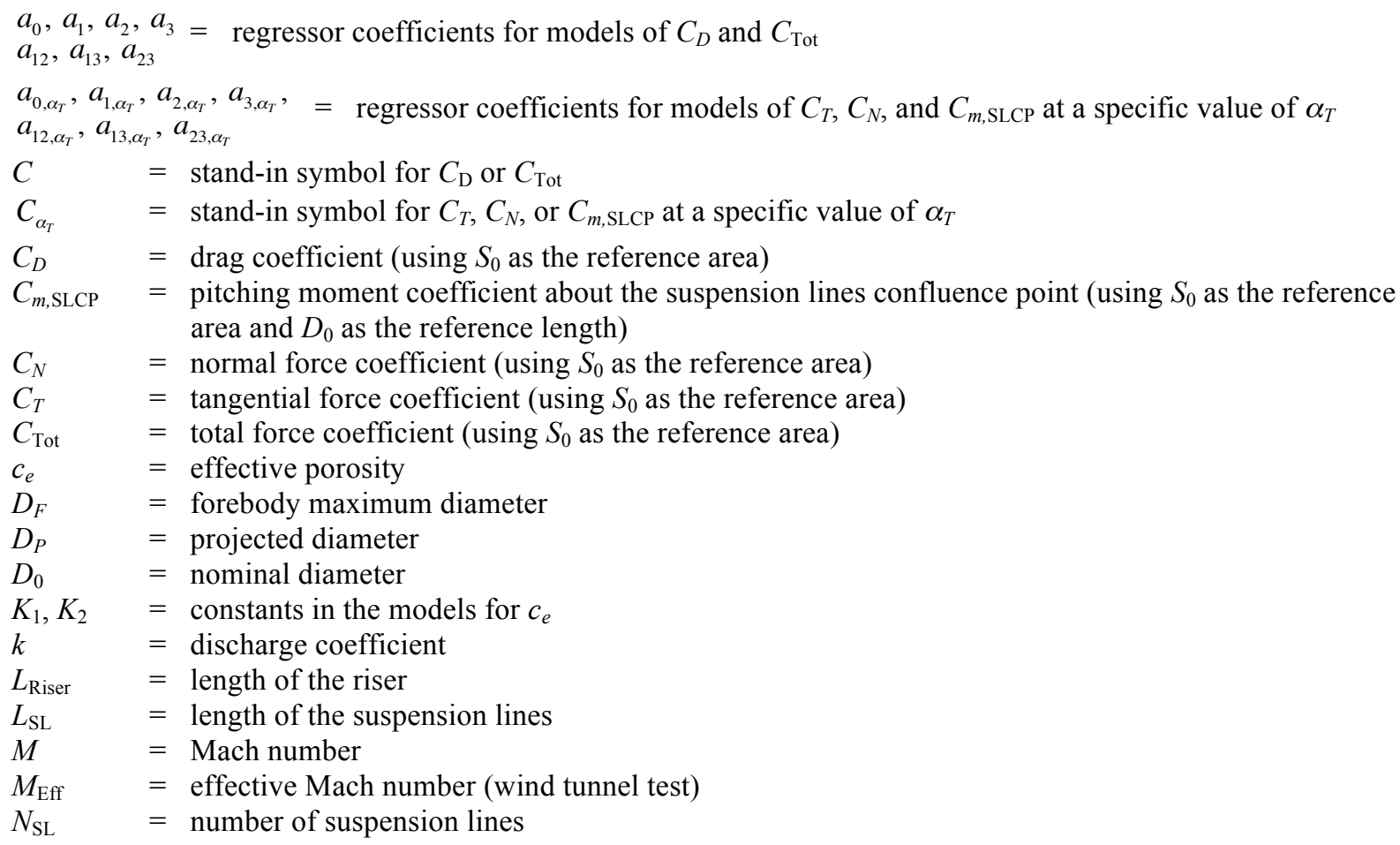

\footnotetext{
* An expanded version of this paper, including the source data, will be published as a NASA Technical Memorandum.

1 Aerospace Engineer, Atmospheric Flight and Entry Systems Branch, AIAA Senior Member.

2 Aerospace Engineer, Aeronautics Systems Engineering Branch.
} 


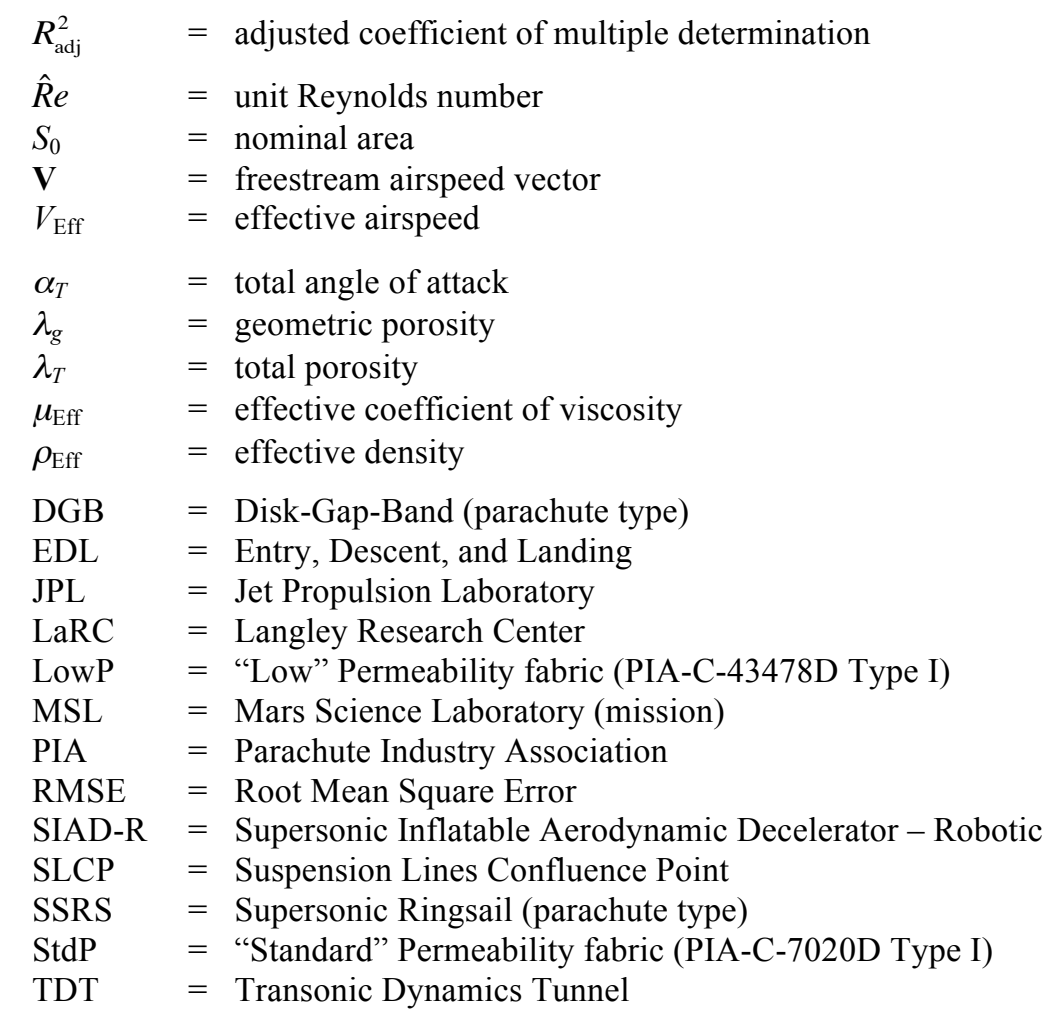

\section{Introduction}

$\mathrm{T}$ HE creation of flight dynamics simulations is often part of the design, development, and flight operations of missions that include entry, descent, and landing (EDL) in their concept of operation. Such flight dynamics simulations include models for many of the EDL sub-systems. For EDL systems that include a parachute, models of the parachute's aerodynamic characteristics must be created for inclusion in the flight dynamics simulations. Examples of such parachute aerodynamic models, as created for the Mars Science Laboratory (MSL) mission, can be found in Reference 1. The parachute aerodynamic models for use in Mars-flight simulations need to take into account the unique operating conditions that missions encounter in the Martian atmosphere. Among these operating conditions are low atmospheric density, low dynamic pressure, and a broad range of Mach numbers (subsonic to supersonic).

This paper presents models for the aerodynamic coefficients of two parachute types suitable for use on Mars. The source data used to create these models were obtained from two test programs. The first test program involved wind tunnel testing of subscale parachutes; this test yielded the source aerodynamic coefficients data (Ref. 2). The second test program involved the measurement of the permeability characteristics of the fabrics used to fabricate the subscale parachute models used in the wind tunnel test (Ref. 3). Using these fabric permeability data, the total porosities, $\lambda_{T}$, of the parachutes were determined.

The drag, $C_{D}$, and total force, $C_{\text {Tot }}$, coefficients were modeled as functions of the total porosity, $\lambda_{T}$, and effective ${ }^{\dagger}$ Mach number, $M_{\text {Eff. }}$ The static coefficients, $C_{T}, C_{N}$, and $C_{m, \text { SLCP }}$ (defined later in this paper), were modeled as functions of $\lambda_{T}, M_{\mathrm{Eff}}$, and the total angle of attack, $\alpha_{T}$. The range of applicability of the models are Mach numbers from approximately 0.25 to 0.50 (for all models) and total angles of attack less than or equal to 17 degrees (for the static coefficients models). The ranges of total porosity values for which the models are valid vary with the parachute type and are specified with the models in subsequent sections of this paper.

In the Source Tests and Data section of this paper the wind tunnel and fabric permeability tests are described, and the results relevant to the paper are presented. The following section, Drag and Total Force Coefficients Modeling,

"The term "effective" in this paper is used to describe the wind tunnel test operating conditions (e.g., Mach number, airspeed, density, coefficient of viscosity) at the parachute canopy, including the correction for wind tunnel blockage. In other words, the "effective" test conditions are the "freestream" test conditions corrected for wind tunnel blockage. In free-flight the effective and freestream conditions are identical. 
describes the creation of, and resulting models for, $C_{D}$ and $C_{\text {Tot }}$. Next, the Static Coefficients Modeling section

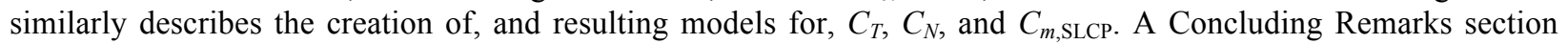
closes the main text of the paper.

\section{Source Tests and Data}

\section{A. Wind Tunnel Test}

A subsonic wind tunnel test of two parachute types for use on missions to Mars was conducted at the NASA Langley Research Center Transonic Dynamics Tunnel (TDT) during November 2014 using subscale model parachutes (Ref. 2). This test was conducted on two types of parachutes: Supersonic Ringsail (SSRS) and Disk-Gap-Band (DGB). These two parachute types, with their appropriate forebodies, are shown in Figures 1 and 2, respectively. The forebodies are the supersonic inflatable aerodynamic decelerator-robotic (SIAD-R) for the SSRS parachutes (Ref. 4), and the MSL backshell for the DGB parachutes (Ref. 1). The presence of the forebodies during the tests was important to capture the effect of their wakes on the parachute aerodynamic characteristics. The scales of the models were 5.0 percent (nominal) for the SSRS parachutes and 6.7 percent (nominal) for the DGB parachutes. All important elements of the parachute and forebody models were geometrically similar to their full-scale counterparts (e.g., trailing distance to parachute diameter ratio, forebody diameter to parachute diameter ratio). Details of the parachutes and forebodies are presented in Table 1. For each of the parachute types, models were fabricated using one of two fabrics described by the Parachute Industry Association (PIA) specifications PIA-C-7020D Type I or PIA-C-44378D Type I . For convenience in notation, these two fabric types will be denoted as "Standard" Permeability (StdP) and "Low" Permeability (LowP), respectively, for the rest of this paper. Thus, there were four parachute type/fabric combinations: SSRS/StdP, SSRS/LowP, DGB/StdP, and DGB/LowP. The two fabrics, StdP and LowP, were manufactured per the PIA specifications cited in References 5 and 6, respectively. These two parachute fabrics have very different permeability characteristics. Using two parachute fabrics with different permeability characteristics allowed for the total porosity of the parachutes to be varied while retaining the same parachute geometry and test conditions. Tests were conducted in air at a variety of densities ${ }^{\ddagger}$ and Mach numbers.

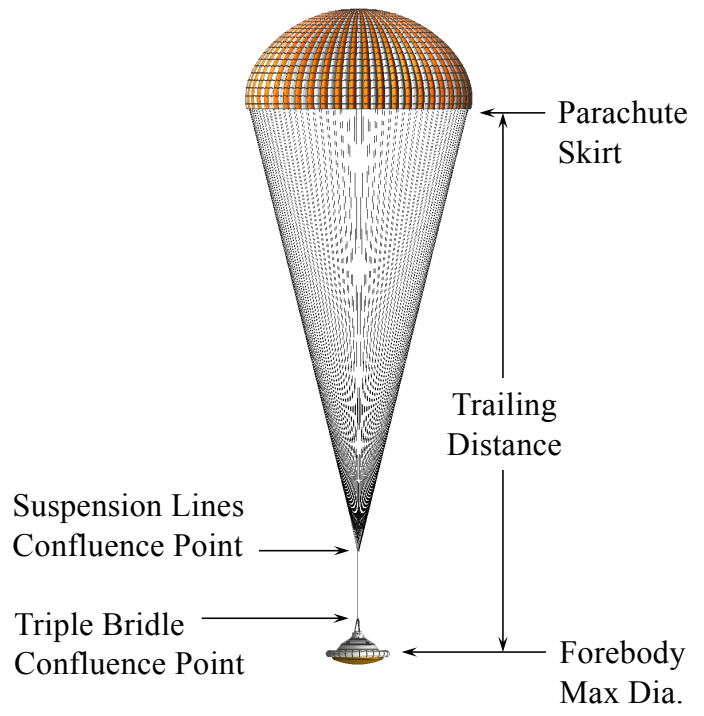

Figure 1. SSRS parachute and SIAD-R forebody overall geometry. (Image credit: JPL)

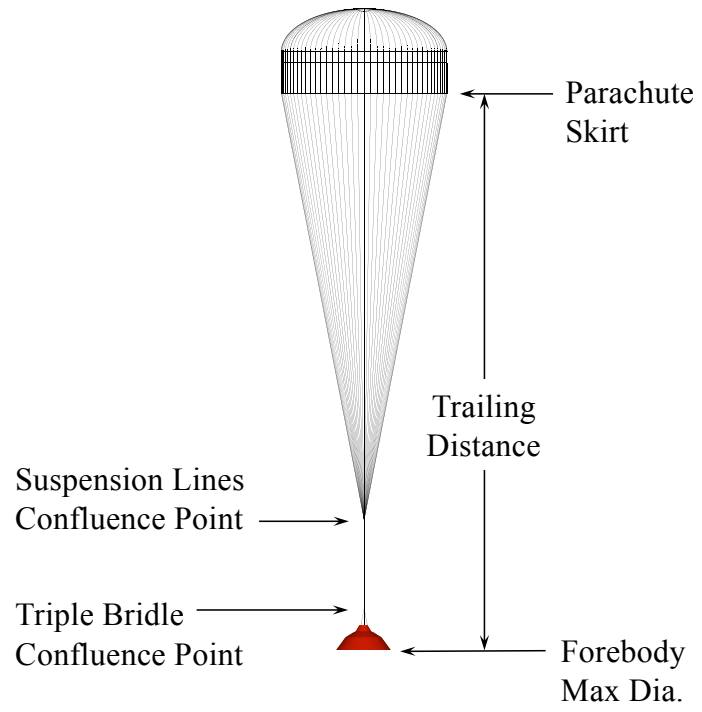

Figure 2. DGB parachute and MSL forebody (backshell) overall geometry. (Backshell image credit: Karl T. Edquist, NASA LaRC)

\# The TDT can operate at very low sub-atmospheric densities. For the wind tunnel test results presented herein, the density varied by a factor of 5.4. 
Table 1. Details of the parachutes and forebodies.

\begin{tabular}{|l|r|r|r|r|}
\cline { 2 - 5 } \multicolumn{1}{c|}{} & \multicolumn{2}{c|}{ SSRS/SIAD-R } & \multicolumn{2}{c|}{ DGB/MSL Backshell } \\
\cline { 2 - 5 } \multicolumn{1}{c|}{} & Full-Scale & \multicolumn{1}{c|}{ Model } & \multicolumn{1}{c|}{ Full-Scale } & \multicolumn{1}{c|}{ Model } \\
\hline Scale (\%) & 100 & 5.0000 & 100 & 6.7041 \\
\hline Nominal Diameter, $D_{0}(\mathrm{ft})$ & 100.1 & 5.003 & 70.04 & 4.696 \\
\hline Nominal Area, $S_{0}\left(\mathrm{ft}^{2}\right)$ & 7864 & 19.66 & 3853 & 17.32 \\
\hline Projected Diameter $/$ Nominal Diameter, $D_{P} / D_{0}$ & & 0.760 & & 0.734 \\
\hline Geometric Porosity, $\lambda_{g}(\%)$ & 14.9 & 15.0 & 12.80 & 12.85 \\
\hline Number of Suspension Lines, $N_{\mathrm{SL}}$ & 96 & 48 & 80 & 40 \\
\hline Suspension Lines Length, $L_{\mathrm{SL}}(\mathrm{ft})$ & 170.1 & 8.506 & 120.0 & 8.045 \\
\hline Riser Length, $L_{\text {Riser }}(\mathrm{ft})$ & 20.02 & 1.001 & 24.76 & 1.660 \\
\hline Forebody Maximum Diameter, $D_{F}(\mathrm{ft})$ & 19.69 & 0.984 & 14.54 & 0.975 \\
\hline $\begin{array}{l}\text { Distance from Forebody Maximum Diameter to } \\
\text { Triple Bridle Confluence Point }(\mathrm{ft})\end{array}$ & 5.167 & 0.258 & 6.41 & 0.430 \\
\hline
\end{tabular}

Notes to Table 1

1) All quantities are as-designed except for $D_{P} / D_{0}$. The as-built parachute/forebody systems have slight variations from the numbers stated here.

2) The ratio $D_{P} / D_{0}$ was determined from photographs taken during the wind tunnel test. This is not an as-designed quantity.

3) The geometric porosity is calculated using the parachute's constrained vent area.

4) The riser length, $L_{\text {Riser }}$, is the distance from the suspension lines confluence point to the triple bridle confluence point. See Figures 1 and 2.

5) Additional details on the DGB parachute geometry can be found in Reference 1.

Results from this wind tunnel test included the parachute drag and total force coefficients $\left(C_{D}\right.$ and $C_{\text {Tot }}$, respectively) as well as the static coefficients $\left(C_{T}, C_{N}\right.$, and $\left.C_{m, \mathrm{SLCP}}\right)$. The forces on the forebodies were not measured; thus, all coefficients were for the parachutes, not the total parachute/forebody system. The test setup for the drag and total force coefficients is shown in Figure 3. The test setup for the static coefficients is shown in Figure 4. Definitions and sign conventions for the static coefficients are shown in Figure 5. Because the parachutes being considered here are assumed to be axisymmetric, the normal force associated with $C_{N}$ lies in the total angle of attack plane. ${ }^{\S}$ Similarly, the pitching moment associated with $C_{m, \text { SLCP }}$ is perpendicular to the total angle of attack plane. Note that the moment defined by $C_{m, \mathrm{SLCP}}$ is about the suspension lines confluence point (SLCP) as shown in Figure 5. The drag and total force coefficients test setup allowed the parachute to oscillate, rotating about the triple bridle confluence point (i.e., the attachment point to the wind tunnel balance). The drag and total force coefficients are "long-term" averages for time intervals during which the parachutes oscillated and occupied various locations downstream of the forebodies. The static coefficients are also "long-term" averages, but the parachute's total angle of attack was held at a fixed value by the test setup during the data acquisition time intervals. All coefficients used the parachute nominal area, $S_{0}$, as the reference area. Moment coefficients used the parachute nominal diameter, $D_{0}$, as the reference length.

This section has just included a brief summary of the model parachutes and wind tunnel test. For more details, the reader should consult Reference 2 .

$\S$ The total angle of attack plane is defined as the plane that includes the freestream airspeed vector, $\mathbf{V}$, and the parachute's axis of symmetry. The plane of the paper in Figure 5 is the total angle of attack plane. 


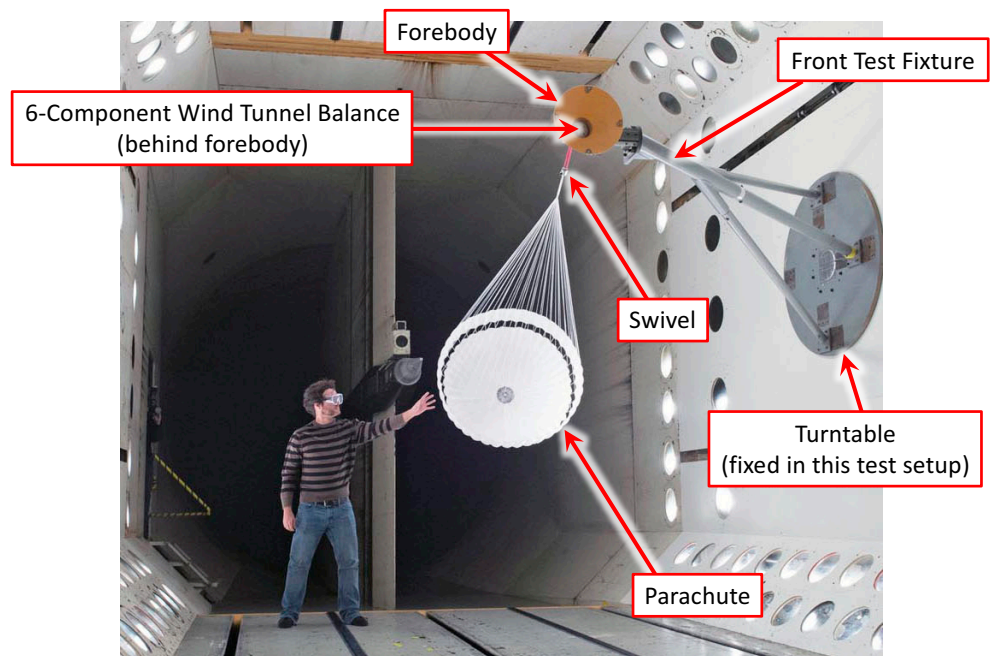

Figure 3. Drag and total force coefficients test setup.

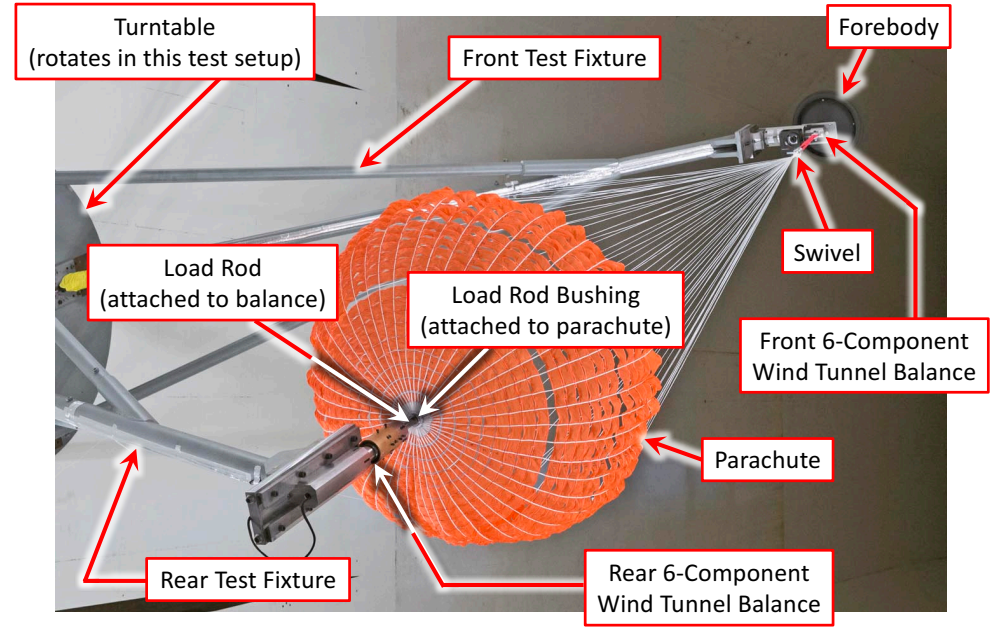

Figure 4. Static coefficients test setup.

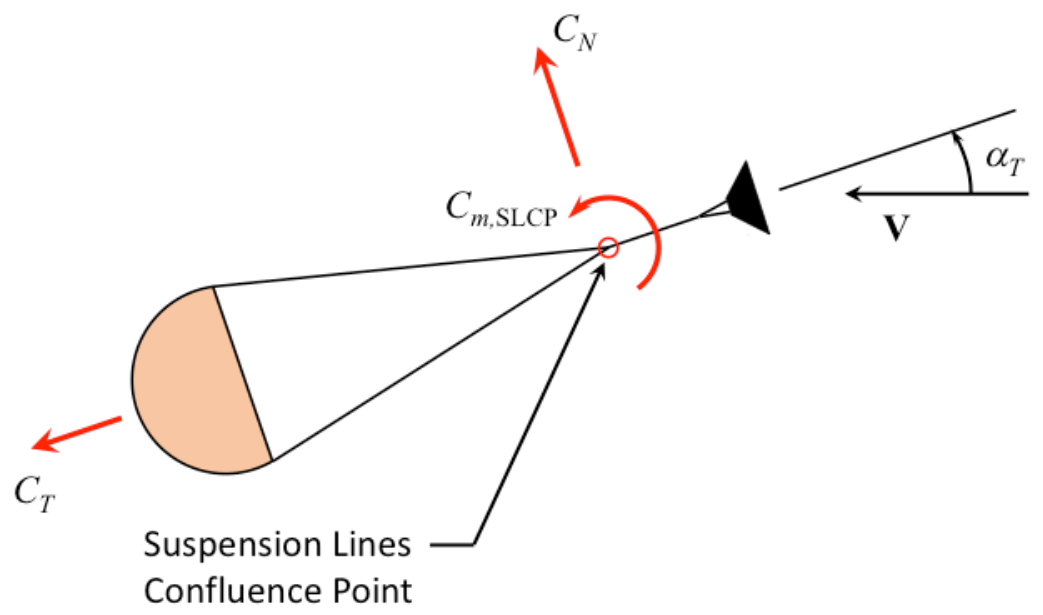

Figure 5. Definition of the static coefficients. 


\section{B. Fabric Permeability, Effective Porosity, and Total Porosity}

The permeability" of the StdP and LowP fabrics was measured in air over a wide range of differential pressures. From these permeability results, the fabric's dimensionless effective porosities, $c_{e}$, were calculated and modeled as functions of the unit Reynolds number, $\hat{R} e$ (the dimension of $\hat{R} e$ is $1 /$ Length). These models for $c_{e}(\hat{R} e)$ were of the form

$$
c_{e}=\frac{-K_{2}}{2 K_{1} \hat{R} e}+\sqrt{\left(\frac{K_{2}}{2 K_{1} \hat{R} e}\right)^{2}+\frac{1}{2 K_{1}}}
$$

where $K_{1}$ and $K_{2}$ are the effective porosity modeling constants $\left(K_{1}\right.$ is dimensionless and $K_{2}$ has the dimension $1 /$ Length), dependent on the fabric type. The value of $\hat{R} e$ was calculated for each parachute and test condition from

$$
\hat{R} e=\frac{\rho_{\mathrm{Eff}} V_{E f f}}{\mu_{\mathrm{Eff}}}\left(\frac{D_{0}}{D_{P}} \sqrt{C_{D}}\right)
$$

where $D_{P}$ is the projected diameter of the parachute, and $\rho_{\mathrm{Eff}}, V_{\mathrm{Eff}}$, and $\mu_{\mathrm{Eff}}$ are the effective test density, airspeed, and coefficient of viscosity, respectively, at the particular test condition (see footnote $\dagger$ for the definition of "effective").

With $c_{e}$ having been calculated, the total porosities of the parachutes were calculated from

$$
\lambda_{T}=k \lambda_{g}+\left(1-\lambda_{g}\right) c_{e}
$$

where $\lambda_{g}$ is the geometric porosity of the parachute, and $k$ is the discharge coefficient. In the present work it was assumed that $k=0.7$. The quantities $k, \lambda_{g}$, and $\lambda_{T}$ are dimensionless.

The approach used here for modeling the fabric permeability and calculating the total porosity was presented by Lingard and Underwood in Reference 7 and Lingard in Reference 8. Details on the permeability and effective porosity of the StdP and LowP fabrics were presented in Reference 3.

\section{Source Data}

It was decided to model the drag, total force, and static coefficients using the total porosity and Mach number as the independent variables. These two quantities were chosen as the independent variables because they (1) are dimensionless, (2) are known to have significant effects on the aerodynamic characteristics, (3) are directly applicable to full-scale parachutes, and (4) yielded good models within the $\left(\lambda_{T}, M_{\mathrm{Eff}}\right)$ range of interest.

The source data used for modeling the drag and total force coefficients for the SSRS and DGB parachutes are presented in Tables 2 and 3, respectively. The Run/Group identification and values of $\lambda_{T}$ and $M_{\text {Eff }}$ for the static coefficients of the SSRS and DGB parachutes are presented in Tables 4 and 5, respectively. (Run/Group is a convenient identifier for a specific parachute type, fabric, and test condition.) The source data for the static coefficients $C_{T}, C_{N}$, and $C_{m, \mathrm{SLCP}}$ as functions of $\alpha_{T}$ for the values of $\lambda_{T}$ and $M_{\mathrm{Eff}}$ listed in Tables 4 and 5 can be found in Reference 9. The complete data set from the wind tunnel test in Reference 2 includes test conditions at lower values of $M_{\mathrm{Eff}}(0.09$ to 0.17$)$. These additional data were not considered in the present work for two reasons. First, because the lower Mach numbers are not likely to occur in a mission to Mars given Mars' thin atmosphere (for example, the descent Mach number of MSL at descent stage separation was 0.324, see Reference 10). Second, because trying to fit the simple models used in the present work over the complete data set (i.e., including the lower values of $\left.M_{\mathrm{Eff}}\right)$ reduced the fidelity of the models in the range of Mach numbers of interest for Mars.

\footnotetext{
" Fabric permeability is the volumetric flow of fluid through the fabric per unit area per unit time $\left(\mathrm{e} . \mathrm{g}\right.$., $\left.\mathrm{ft}^{3} /\left(\mathrm{ft}^{2} \cdot \mathrm{s}\right)\right)$ at a given differential pressure across the fabric.
} 
Table 2. Drag and total force coefficient data for the SSRS parachutes.

\begin{tabular}{|c|c|c|c|c|r|}
\hline Fabric Type & Run/Group & $\lambda_{T}$ & $M_{\text {Eff }}$ & \multicolumn{1}{c|}{$C_{D}$} & \multicolumn{1}{c|}{$C_{\text {Tot }}$} \\
\hline \multirow{5}{*}{ StdP } & $15 / 47$ & 0.1411 & 0.257 & 0.612 & 0.613 \\
\cline { 2 - 6 } & $15 / 46$ & 0.1365 & 0.257 & 0.618 & 0.619 \\
\cline { 2 - 6 } & $15 / 45$ & 0.1367 & 0.333 & 0.622 & 0.622 \\
\cline { 2 - 6 } & $15 / 44$ & 0.1284 & 0.258 & 0.626 & 0.626 \\
\cline { 2 - 6 } & $15 / 43$ & 0.1336 & 0.516 & 0.643 & 0.644 \\
\cline { 2 - 6 } & $15 / 42$ & 0.1277 & 0.413 & 0.637 & 0.637 \\
\cline { 2 - 6 } & $15 / 41$ & 0.1290 & 0.517 & 0.650 & 0.651 \\
\hline \multirow{5}{*}{ LowP } & $12 / 33$ & 0.1063 & 0.261 & 0.658 & 0.658 \\
\cline { 2 - 6 } & $12 / 32$ & 0.1062 & 0.337 & 0.667 & 0.668 \\
\cline { 2 - 6 } & $12 / 31$ & 0.1060 & 0.263 & 0.651 & 0.655 \\
\cline { 2 - 6 } & $12 / 30$ & 0.1060 & 0.420 & 0.676 & 0.677 \\
\cline { 2 - 6 } & $12 / 29$ & 0.1061 & 0.523 & 0.702 & 0.702 \\
\hline
\end{tabular}

Table 3. Drag and total force coefficient data for the DGB parachutes.

\begin{tabular}{|c|c|c|r|r|r|}
\hline Fabric Type & Run/Group & $\lambda_{T}$ & \multicolumn{1}{c|}{$M_{\text {Eff }}$} & \multicolumn{1}{c|}{$C_{D}$} & \multicolumn{1}{c|}{$C_{\text {Tot }}$} \\
\hline \multirow{5}{*}{ StdP } & $17 / 68$ & 0.1212 & 0.255 & 0.564 & 0.564 \\
\cline { 2 - 6 } & $17 / 67$ & 0.1163 & 0.254 & 0.565 & 0.565 \\
\cline { 2 - 6 } & $17 / 66$ & 0.1166 & 0.331 & 0.568 & 0.568 \\
\cline { 2 - 6 } & $17 / 65$ & 0.1083 & 0.255 & 0.573 & 0.573 \\
\cline { 2 - 6 } & $17 / 64$ & 0.1134 & 0.513 & 0.586 & 0.586 \\
\cline { 2 - 6 } & $17 / 63$ & 0.1073 & 0.409 & 0.583 & 0.584 \\
\cline { 2 - 6 } & $17 / 62$ & 0.1087 & 0.512 & 0.589 & 0.589 \\
\hline \multirow{5}{*}{ LowP } & $16 / 56$ & 0.0847 & 0.256 & 0.631 & 0.632 \\
\cline { 2 - 6 } & $16 / 55$ & 0.0844 & 0.256 & 0.621 & 0.624 \\
\cline { 2 - 6 } & $16 / 54$ & 0.0844 & 0.332 & 0.623 & 0.624 \\
\cline { 2 - 6 } & $16 / 53$ & 0.0841 & 0.257 & 0.618 & 0.623 \\
\cline { 2 - 6 } & $16 / 52$ & 0.0843 & 0.514 & 0.644 & 0.644 \\
\cline { 2 - 6 } & $16 / 51$ & 0.0841 & 0.411 & 0.626 & 0.629 \\
\cline { 2 - 6 } & $16 / 60$ & 0.0842 & 0.514 & 0.642 & 0.643 \\
\hline
\end{tabular}


Table 4. Values of $\lambda_{T}$ and $M_{\text {Eff }}$ for the static coefficients data of the SSRS parachutes.

\begin{tabular}{|c|c|c|c|}
\hline Fabric Type & Run/Group & $\lambda_{T}$ & $M_{\text {Eff }}$ \\
\hline \multirow{5}{*}{ StdP } & $21 / 8$ & 0.1411 & 0.257 \\
\cline { 2 - 4 } & $21 / 7$ & 0.1365 & 0.257 \\
\cline { 2 - 4 } & $21 / 6$ & 0.1368 & 0.333 \\
\cline { 2 - 4 } & $20 / 5$ & 0.1292 & 0.257 \\
\cline { 2 - 4 } & $20 / 4$ & 0.1340 & 0.515 \\
\cline { 2 - 4 } & $19 / 3$ & 0.1275 & 0.410 \\
\cline { 2 - 4 } & $19 / 2$ & 0.1295 & 0.514 \\
\hline \multirow{5}{*}{ LowP } & $25 / 29$ & 0.1066 & 0.256 \\
\cline { 2 - 4 } & $25 / 28$ & 0.1063 & 0.256 \\
\cline { 2 - 4 } & $25 / 27$ & 0.1063 & 0.333 \\
\cline { 2 - 4 } & $25 / 26$ & 0.1060 & 0.256 \\
\cline { 2 - 4 } & $25 / 25$ & 0.1062 & 0.515 \\
\cline { 2 - 4 } & $25 / 24$ & 0.1060 & 0.411 \\
\cline { 2 - 4 } & $25 / 23$ & 0.1061 & 0.515 \\
\hline
\end{tabular}

Table 5. Values of $\lambda_{T}$ and $M_{\text {Eff }}$ for the static coefficients data of the DGB parachutes.

\begin{tabular}{|c|c|c|c|}
\hline Fabric Type & Run/Group & \multicolumn{1}{|c|}{$\lambda_{T}$} & \multicolumn{1}{|c|}{$M_{\text {Eff }}$} \\
\hline \multirow{5}{*}{ StdP } & $31 / 43$ & 0.1213 & 0.256 \\
\cline { 2 - 4 } & $29 / 41$ & 0.1165 & 0.255 \\
\cline { 2 - 4 } & $29 / 40$ & 0.1167 & 0.331 \\
\cline { 2 - 4 } & $29 / 39$ & 0.1085 & 0.256 \\
\cline { 2 - 4 } & $29 / 38$ & 0.1137 & 0.513 \\
\cline { 2 - 4 } & $29 / 37$ & 0.1077 & 0.410 \\
\cline { 2 - 4 } & $29 / 36$ & 0.1089 & 0.514 \\
\hline \multirow{5}{*}{ LowP } & $33 / 52$ & 0.0847 & 0.256 \\
\cline { 2 - 4 } & $33 / 51$ & 0.0844 & 0.257 \\
\cline { 2 - 4 } & $33 / 50$ & 0.0844 & 0.333 \\
\cline { 2 - 4 } & $33 / 49$ & 0.0841 & 0.258 \\
\cline { 2 - 4 } & $33 / 48$ & 0.0843 & 0.515 \\
\cline { 2 - 4 } & $33 / 47$ & 0.0841 & 0.412 \\
\cline { 2 - 4 } & $33 / 46$ & 0.0842 & 0.515 \\
\hline
\end{tabular}

\section{Drag and Total Force Coefficients Modeling}

Linear regression models of the general form

$$
C=a_{0}+a_{1} \lambda_{T}+a_{2} M_{\mathrm{Eff}}+a_{12} \lambda_{T} M_{\mathrm{Eff}}
$$

were created for the SSRS and DGB parachutes using the method of least squares. The quantity $C$ in Equation (4) represents either $C_{D}$ or $C_{\text {Tot }}$ as necessary. Not all regressor coefficients (i.e., $a_{0}, a_{1}, a_{2}$, and $a_{12}$ ) were used for all models. The chosen models were those that maximized $R_{\text {adj }}^{2}$ subject to the requirement that all regressor coefficients had to have a $p$-value of 0.05 or less." The linear regression models for $C_{D}$ and $C_{\text {Tot }}$ are presented in Table 6. Note that for these models to be valid, $\lambda_{T}$ needs to be calculated as described by Equation (3) with $k=0.7$.

\footnotetext{
\# The regression and statistics were calculated using the JMP software published by SAS (Ref. 11).
} 
Table 6. Models for $C_{D}$ and $C_{\text {Tot }}$.

\begin{tabular}{|c|c|c|c|c|c|c|c|c|c|}
\hline $\begin{array}{c}\text { Parachute } \\
\text { Type }\end{array}$ & Coef. & $a_{0}$ & $a_{1}$ & $a_{2}$ & $a_{12}$ & $R_{\text {adj }}^{2}$ & RMSE & $\begin{array}{c}\text { Max. } \\
p \text {-value }\end{array}$ & $\begin{array}{c}\text { Max. } \\
\mid \text { residual } \mid\end{array}$ \\
\hline \multirow{2}{*}{ SSRS } & $C_{D}$ & 0.6031750 & Not included & 0.6312282 & -4.199903 & 0.9808 & 0.00365 & $<0.0001$ & 0.006 \\
\cline { 2 - 10 } & $C_{\text {Tot }}$ & 0.6052009 & Not included & 0.6339054 & -4.245635 & 0.9798 & 0.00374 & $<0.0001$ & 0.006 \\
\hline \multirow{2}{*}{ DGB } & $C_{D}$ & 0.7602148 & -1.811319 & 0.0578995 & Not included & 0.9617 & 0.00579 & 0.0019 & 0.009 \\
\cline { 2 - 10 } & $C_{\text {Tot }}$ & 0.7690143 & -1.872619 & 0.0533234 & Not included & 0.9668 & 0.00552 & 0.0024 & 0.008 \\
\hline
\end{tabular}

RMSE - Root Mean Square Error

The values of $\lambda_{T}$ and $M_{\text {Eff }}$ used to create the models (see Tables 2 and 3) are plotted versus each other in Figures 6 and 7 for the SSRS and DGB parachutes, respectively. Dotted lines show the boundaries of the convex hull domains defined by the $\left(\lambda_{T}, M_{\mathrm{Eff}}\right)$ points. Applying the models at points within the dotted lines is interpolation; otherwise it is extrapolation. Inequalities approximately defining the domain boundaries for the SSRS and DGB parachutes are presented in Equations (5) and (6), respectively. All inequalities must be satisfied for a point to be inside the domain. Using the models at points outside their convex hulls is not recommended as they may yield inaccurate values of the drag and total force coefficients.

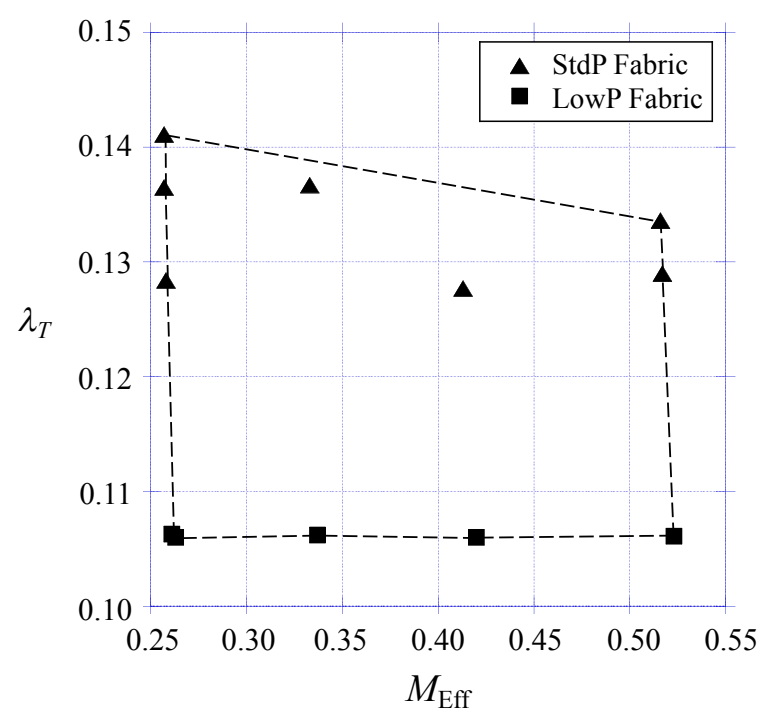

Figure 6. Domain of the $C_{D}$ and $C_{\text {Tot }}$ models for the SSRS parachutes.

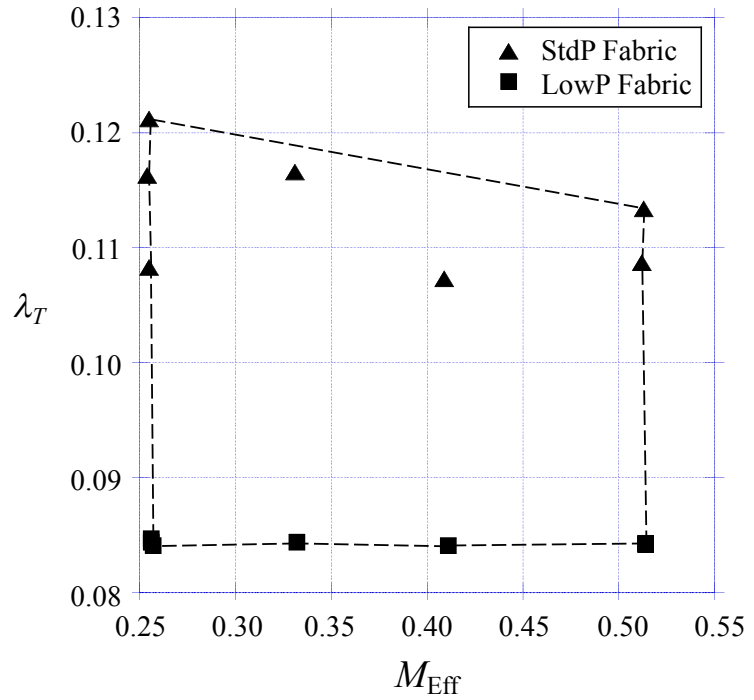

Figure 7. Domain of the $C_{D}$ and $C_{\text {Tot }}$ models for the DGB parachutes.

SSRS parachute domain definition for the $C_{D}$ and $C_{\text {Tot }}$ models

$$
\begin{gathered}
0.263 \leq M_{\text {Eff }} \leq 0.517 \\
\lambda_{T} \geq 0.1063 \\
\lambda_{T} \leq 0.1486-0.02906 M_{\text {Eff }}
\end{gathered}
$$

DGB parachute domain definition for the $C_{D}$ and $C_{\text {Tot }}$ models

$$
\begin{gathered}
0.257 \leq M_{\text {Eff }} \leq 0.512 \\
\lambda_{T} \geq 0.0847 \\
\lambda_{T} \leq 0.1290-0.03057 M_{\text {Eff }}
\end{gathered}
$$

Notice that the models defined by Equation (4) included only the linear and interaction regressors $\lambda_{T}, M_{\text {Eff, }}$, and $\lambda_{T} M_{\mathrm{Eff}}$. Quadratic regressors such as $\lambda_{T}^{2}$ and $M_{\mathrm{Eff}}^{2}$ were intentionally not included in the models. The reason for this was that there were few data points inside the domains, as can be seen from Figures 6 and 7; most points 
were on the boundaries of the domains. This limited number of data points within the domains casted doubt on the accurate identification of coefficients associated with quadratic regressors. In addition, models with quadratic coefficients would be more likely to yield inaccurate values of $C_{D}$ and $C_{\text {Tot }}$ if applied outside their domains (i.e., when extrapolating). The models defined by Equation (4) are considered to be more robust to minor extrapolations.

Other dimensionless independent variables and regressors were considered for inclusion in the linear regression models. Inclusion of other regressors yielded small improvements in the fidelity of the models as determined from $R_{\text {adj }}^{2}$. However, these regressors exhibited significant collinearity. Thus, it was not possible to identify which regressor should be added to the models for full-scale parachute applications. Because of the small accuracy improvements, and the difficulty in identifying the appropriate additional regressor to add to the models, the models described by Equation (4) were used in the present work. Additional discussion on this topic is presented in Reference 9.

A partial check of the validity of the $C_{\text {Tot }}$ model for the DGB parachute was conducted using data from the MSL mission (Ref. 10). Figure 8 shows the values of $C_{\text {Tot }}$ for the MSL flight reconstruction and the present DGB model. The light gray line in this figure is the raw data from the MSL reconstruction over the Mach number interval for which the present DGB model is valid [see Equation (6)], and reconstruction data are available. This interval contains $89.92 \mathrm{~s}$ of the parachute phase of MSL; it ends with descent stage separation at a Mach number of 0.324 . The oscillations in these raw data are expected; they are due to unsteadiness in the aerodynamic total force and parachute/payload oscillations. The dashed black line is a linear least squares fit to the raw data from the MSL reconstruction. (Note: the total uncertainty (includes both precision and bias uncertainties) in the MSL reconstruction on individual values of $C_{\text {Tot }}$ was estimated to be \pm 0.052 at the 95 percent level of confidence; see Reference 10, Table 7.) From the MSL reconstruction the values of $\lambda_{T}$ and Mach number, $M$, were calculated.* ( $M$ is the equivalent of $M_{\mathrm{Eff}}$ in the present context.) The solid black line shows the results of the present DGB model using the values of $\lambda_{T}$ and $M$ obtained from the MSL reconstruction. ${ }^{\dagger \dagger}$ The agreement between the linear fit of the reconstruction data and the present model is very good. At the lowest Mach number $(M=0.324)$, the two values of $C_{\text {Tot }}$ agree within 0.5 percent. At the upper Mach number $(M=0.512)$, the two values of $C_{\text {Tot }}$ agree within 5 percent. Given the many steps and data required to create the present model, the agreement with the MSL flight reconstruction data is encouraging with regard to the accuracy of the present model.

** The reconstructed values of $C_{\text {Tot }}$ were used in lieu of $C_{D}$ in Equation (2) to calculate $\hat{R} e$, and subsequently $c_{e}$ and $\lambda_{T}$ from Equations (1) and (3), respectively. The values of $C_{\text {Tot }}$ and $C_{D}$ were close enough to make this substitution acceptable. During the portion of the parachute phase discussed here $(0.324 \leq M \leq 0.512)$, the total porosity was nearly constant, with a range of $0.0930 \leq \lambda_{T} \leq 0.0945$. This range in $\lambda_{T}$ yields a variation of $C_{\text {Tot }}$ less than 0.003 .

it Approximately 91 percent of the fabric used to fabricate the MSL parachute was PIA-C-7020B Type I and PIA-C-7020C Type I. These fabrics have the same permeability specifications as the PIA-C-7020D Type I (StdP) fabric. All three of these "7020" fabrics are woven using nylon fiber. The remaining 9 percent of the fabric used to fabricate the MSL parachute was woven to a proprietary Pioneer Aerospace specification using polyester fibers. (See Reference 10 for more details on the MSL parachute.) The polyester fabric had a measured fabric permeability 9 percent higher than the StdP fabric at a differential pressure of 0.5 inches of water (standard test conditions in the U.S.). In the analysis presented here, the MSL parachute is assumed to have been constructed in its entirety from StdP fabric. Because of the small area of the MSL parachute that used the polyester fabric, and the small difference in fabric permeability between the polyester fabric and the StdP fabric, the assumption that the entire MSL parachute was constructed from StdP fabric has a negligible effect on the values of $C_{\text {Tot }}$ calculated by the model and reported here. 


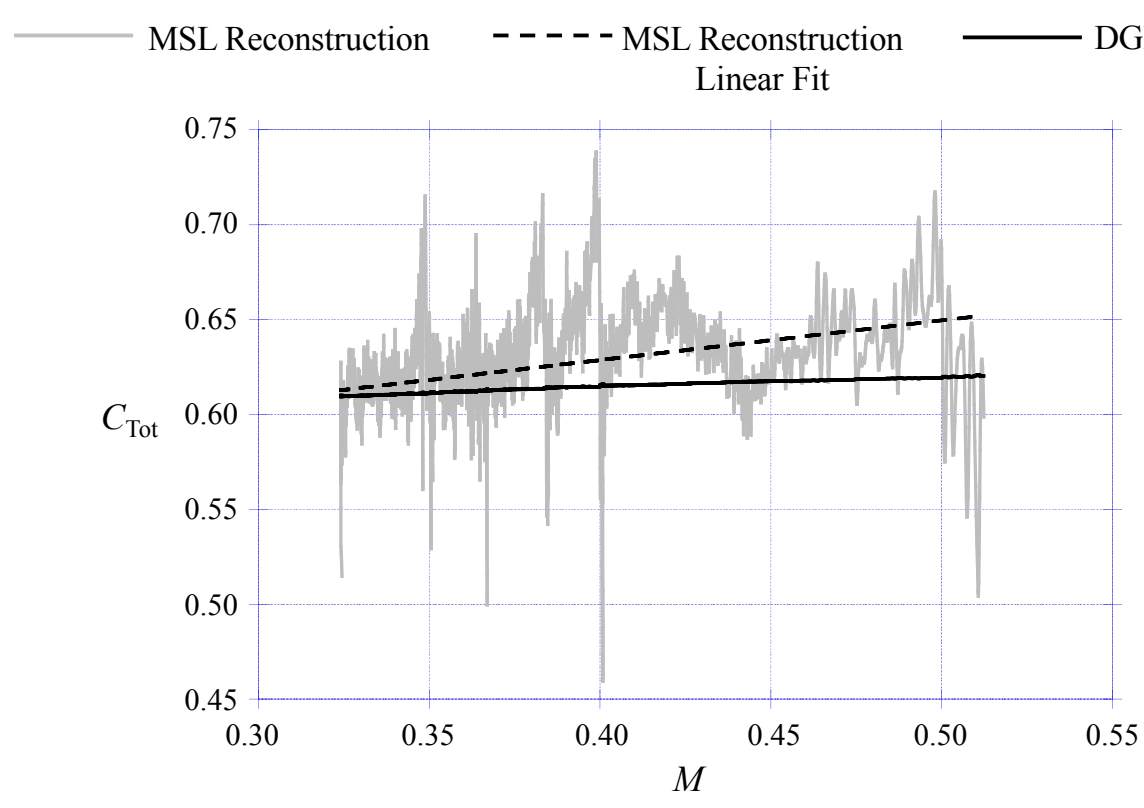

Figure 8. Comparison of the $C_{T o t}$ values from the MSL reconstruction and the present model for the DGB parachute.

\section{Static Coefficients Modeling}

Linear regression models of the general form

$$
C_{\alpha_{T}}=a_{0, \alpha_{T}}+a_{1, \alpha_{T}} \lambda_{T}+a_{2, \alpha_{T}} M_{\mathrm{Eff}}+a_{12, \alpha_{T}} \lambda_{T} M_{\mathrm{Eff}}
$$

were created for the SSRS and DGB parachutes using the method of least squares. ${ }^{\S \S}$ The quantity $C_{\alpha_{T}}$ in Equation (7) represents $C_{T}, C_{N}$, or $C_{m, \mathrm{SLCP}}$ as necessary for a specific value of $\alpha_{T}$. The regressor coefficients, $a_{0, \alpha_{T}}$, $a_{1, \alpha_{T}}, a_{2, \alpha_{T}}$, and $a_{12, \alpha_{T}}$, are associated with the same specific value of $\alpha_{T}$ associated with its corresponding $C_{\alpha_{T}}$. Thus, as an example, for a given parachute type (SSRS or DGB) at $\alpha_{T}=4.8^{\circ}$,

$$
C_{T, \alpha_{T}=4.8^{\circ}}=a_{0, \alpha_{T}=4.8^{\circ}}+a_{1, \alpha_{T}=4.8^{\circ}} \lambda_{T}+a_{2, \alpha_{T}=4.8^{\circ}} M_{\mathrm{Eff}}+a_{12, \alpha_{T}=4.8^{\circ}} \lambda_{T} M_{\mathrm{Eff}}
$$

where the values of the regressor coefficients, $a_{0, \alpha_{T}=4.8^{\circ}}, a_{1, \alpha_{T}=4.8^{\circ}}, a_{2, \alpha_{T}=4.8^{\circ}}$, and $a_{12, \alpha_{T}=4.8^{\circ}}$, are specific to $C_{T}$ at $\alpha_{T}=4.8^{\circ}$ and the parachute type. All models retained all regressor coefficients, $a_{0, \alpha_{T}}, a_{1, \alpha_{T}}, a_{2, \alpha_{T}}$, and $a_{12, \alpha_{T}}{ }^{\text {If }}$ The linear regression models for $C_{T}, C_{N}$, and $C_{m \text {,SLCP }}$ (i.e., the values of the regressor coefficients, $a_{0, \alpha_{T}}, a_{1, \alpha_{T}}, a_{2, \alpha_{T}}$, and $a_{12, \alpha_{T}}$ ) are presented in the Appendix. For the static coefficient models to be valid, $\lambda_{T}$ needs to be calculated as described by Equation (3) with $k=0.7$.

The values of $\lambda_{T}$ and $M_{\text {Eff }}$ used to create the models (see Tables 4 and 5) are plotted versus each other in Figures 9 and 10 for the SSRS and DGB parachutes, respectively. Dotted lines show the boundaries of the convex hull domains defined by the $\left(\lambda_{T}, M_{\mathrm{Eff}}\right)$ points. Applying the models at points within the dotted lines is interpolation; otherwise it is extrapolation. Inequalities approximately defining the domain boundaries for the SSRS and DGB parachutes are presented in Equations (9) and (10), respectively. These inequalities must be satisfied for a point to be inside the domains. As with the $C_{D}$ and $C_{\text {Tot }}$ models, using the static coefficient models at points outside their convex hulls is not recommended as they may yield inaccurate values of the static coefficients.

$\S$ The source static coefficient source data (i.e., $C_{T}, C_{N}$, and $C_{m, \text { SLCP }}$ as functions of $\alpha_{T}$ ), are presented in Reference 9 for the Run/Group and values of $\lambda_{T}$ and $M_{\text {Eff }}$ specified in Tables 4 and 5. The range of $\alpha_{T}$ for these data are from 0 to 17 degrees, at intervals of 0.2 degrees. These source static coefficient data were used to create the models.

9T Note that functions of $\alpha_{T}$ were not used in the models for the static coefficients. The relationships between the static coefficients and $\alpha_{T}$ are complex and difficult to model with simple functions. 


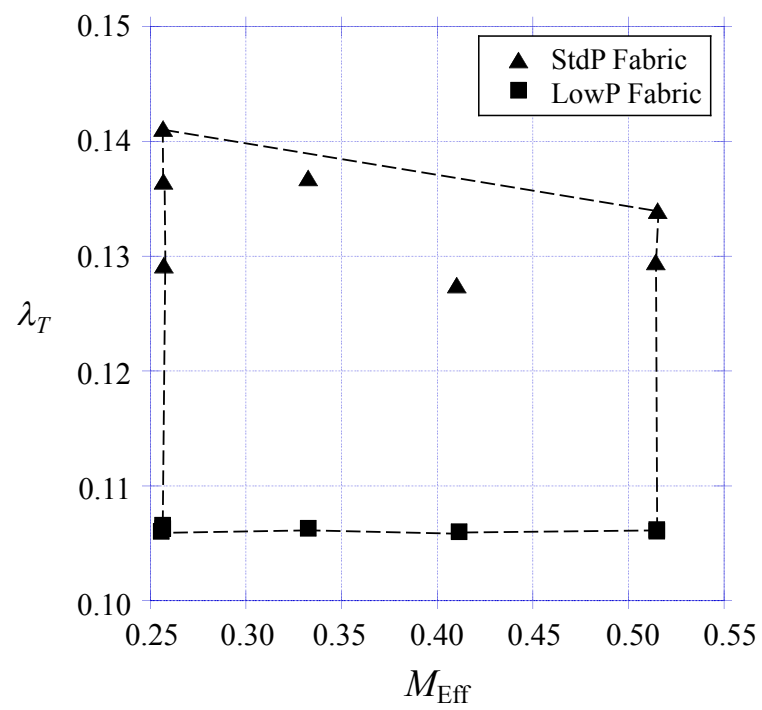

Figure 9. Domain of the $C_{T}, C_{N}$, and $C_{m \text {, SLCP }}$ models for the SSRS parachutes.

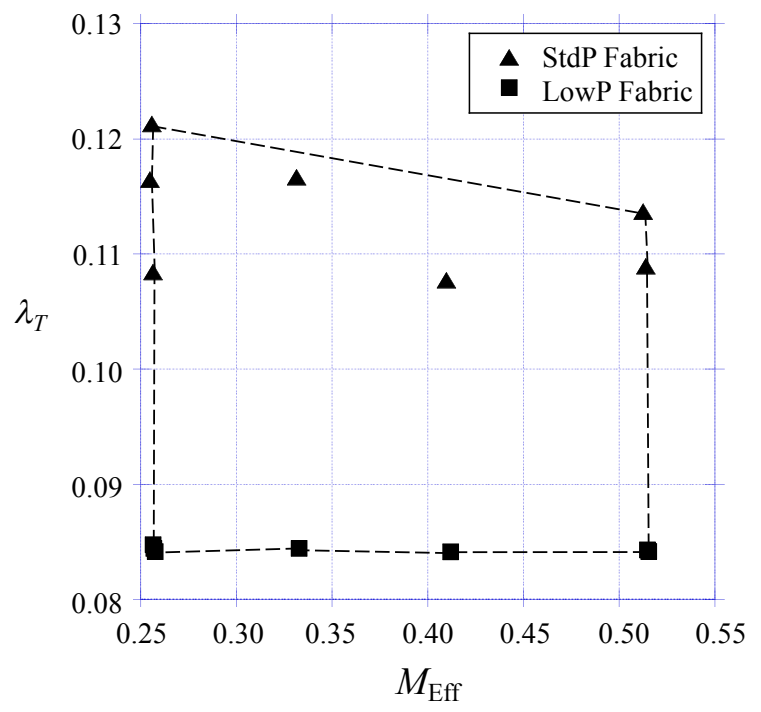

Figure 10. Domain of the $C_{T}, C_{N}$, and $C_{m \text {, SLCP }}$ models for the DGB parachutes.

SSRS parachute domain definition for the static coefficient models

$$
\begin{gathered}
0.257 \leq M_{\mathrm{Eff}} \leq 0.514 \\
\lambda_{T} \geq 0.1066 \\
\lambda_{T} \leq 0.1482-0.02765 M_{\mathrm{Eff}}
\end{gathered}
$$

DGB parachute domain definition for the static coefficient models

$$
\begin{gathered}
0.257 \leq M_{\mathrm{Eff}} \leq 0.513 \\
\lambda_{T} \geq 0.0847 \\
\lambda_{T} \leq 0.1289-0.02964 M_{\mathrm{Eff}}
\end{gathered}
$$

The models defined by Equation (7) include only the linear and interaction regressors: $\lambda_{T}, M_{\mathrm{Eff}}$, and $\lambda_{T} M_{\mathrm{Eff}}$. Quadratic regressors such as $\lambda_{T}^{2}$ and $M_{\mathrm{Eff}}^{2}$ were intentionally not included in the models. The reasons for this selection of regressors are the same as those described for the drag and total force coefficient models.

Other dimensionless independent variables and regressors were considered for inclusion in the linear regression models for the static coefficients. As was the case with the $C_{D}$ and $C_{\text {Tot }}$ models, adding other dimensionless regressors yielded some improvements in the fidelity of the static coefficient models. However, it was decided not to include any additional regressors to the models - the improvements were considered to have detrimental effects on the applicability of the models to full-scale parachutes. Thus, the models described by Equation (7) were used in the present work. Additional discussion on this topic is presented in Reference 9.

The fidelity of the models was evaluated by comparing the source static coefficient data against the values predicted by the models. The following observations were made from these comparisons:

1) In general the models performed well in reproducing the source static coefficient data.

2) The models were better at reproducing the source data for $C_{T}$ as compared to $C_{N}$ and $C_{m, \mathrm{SLCP}}$.

3) The overall fidelity of the models was better for parachutes fabricated from LowP fabric as compared to those fabricated from StdP fabric.

4) No significant difference was found in the overall fidelity of the models for the SSRS parachutes and the DGB parachutes.

Some of the Run/Group with the largest discrepancies between the source static coefficient data and the models were selected for more detailed inspection, including consideration of the uncertainties associated with the source static coefficient data. The largest difference in $C_{T}$ between the source static coefficient data and the model was 
observed in Run 19, Group 3 (SSRS/StdP parachute, $\lambda_{T}=0.1275, M_{\mathrm{Eff}}=0.410$ ). Figure 11 shows $C_{T}$ versus $\alpha_{T}$ for the source data (thin solid line with uncertainty bars) and the model (dashed line). The uncertainty bars in Figure 11 show the 95 percentile confidence interval around the source data, including both precision and bias uncertainty. As can be seen from Figure 11, the model values are within the specified confidence interval around the source data. Thus, the difference between the source data and the model values vis-à-vis the confidence interval, and the absolute maximum difference between the source data and the model values (1.9 percent), do not constitute a significant degradation in the accuracy of the values of $C_{T}$ calculated from the model. For all other Runs/Groups the difference between the source data and model values for $C_{T}$ are less than that for Run 19, Group 3.

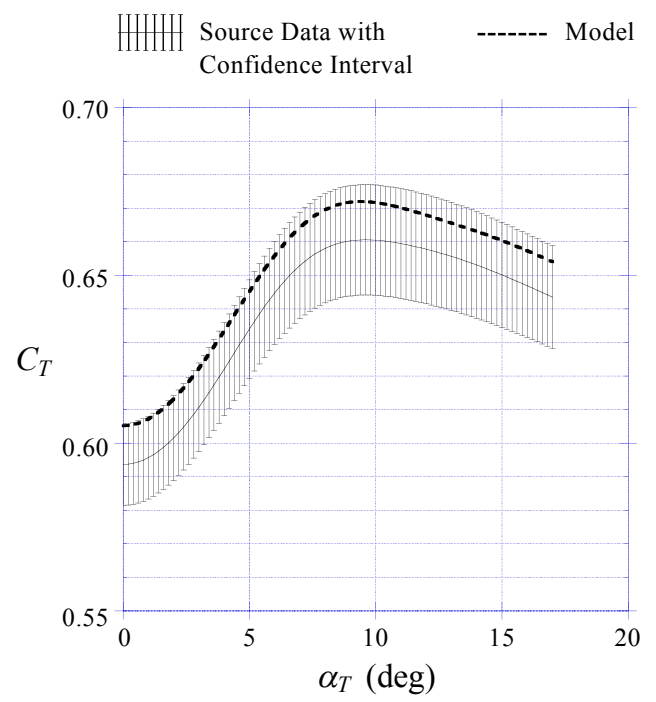

Figure 11. Static coefficient $C_{T}$ versus $\alpha_{T}$ for the SSRS/StdP parachute, Run 19/Group 3, $\lambda_{T}=0.1275, M_{\mathrm{Eff}}=0.410$.

Significant differences in $C_{N}$ and $C_{m, \text { SLCP }}$ were observed for Run 20, Group 5 (SSRS/StdP parachute, $\lambda_{T}=0.1292$, $\left.M_{\mathrm{Eff}}=0.257\right)$ and Run 25, Group $28\left(\mathrm{SSRS} /\right.$ LowP parachute, $\left.\lambda_{T}=0.1063, M_{\mathrm{Eff}}=0.256\right)$. Figure 12 shows $C_{N}$ and $C_{m, \mathrm{SLCP}}$ versus $\alpha_{T}$ for the source data (thin solid lines with uncertainty bars) and the models (dashed lines) for Run/Group $20 / 5$ and $25 / 28$. The meaning of the uncertainty bars is the same as that for Figure 11 . For the

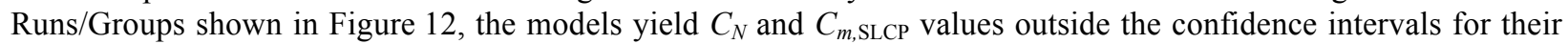
respective source data for some values of $\alpha_{T}$.

The differences between the source static coefficients data and the models have multiple sources, two of which are discussed here. First is the simplicity of the model in Equation (7), which contains only the first order linear terms in $l_{T}$ and $M_{\mathrm{Eff}}$ and their interaction term $\lambda_{T} M_{\mathrm{Eff}}$. Even if the only independent variables retained were $\lambda_{T}$ and

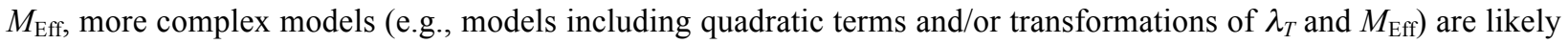
to have yielded better fidelity vis-à-vis the source static coefficients data. However, as discussed earlier, the simpler models used herein were chosen due to the distribution of the source static coefficients data within their domains and the perceived higher robustness of simpler models with respect to minor extrapolations in their use. A second source for the differences between the source static coefficients data and the models is likely to be the absence of other relevant dimensionless coefficients as independent variables (this issue is discussed in Reference 9). 

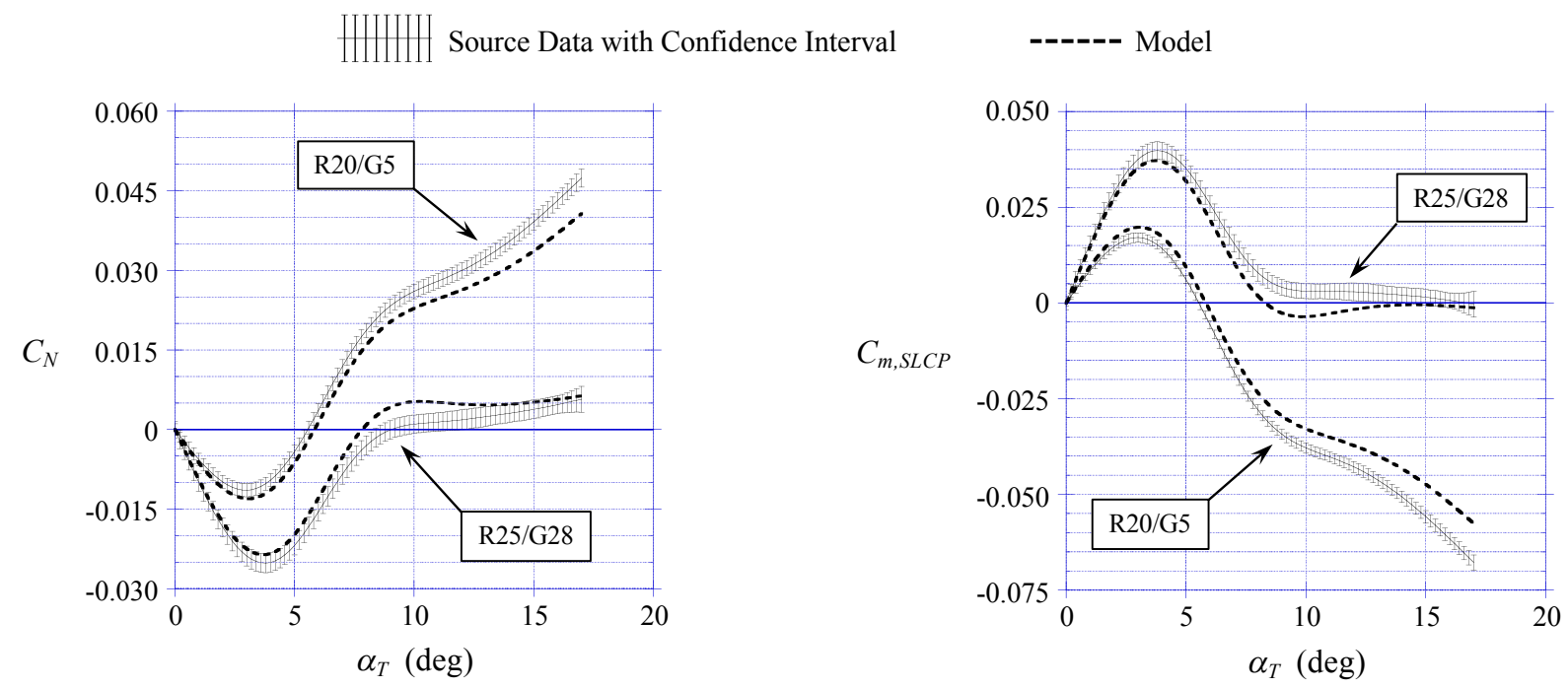

Figure 13. Static coefficients $C_{N}$ and $C_{m, \mathrm{SLCP}}$ versus $\alpha_{T}$ for the

SSRS/StdP parachute, Run 20/Group 5, $\lambda_{T}=0.1292, M_{\mathrm{Eff}}=0.257$, and the

SSRS/LowP parachute, Run 25/Group 28, $\lambda_{T}=0.1063, M_{\mathrm{Eff}}=0.256$.

The models were used to calculate the static coefficients of the MSL parachute, assuming it was fabricated from StdP fabric (see footnote $\uparrow \dagger$ ). These calculations were performed at two flight conditions: the upper and lower Mach number limits shown in Figure 8. The corresponding values of $\lambda_{T}$ were calculated from the reconstructed MSL flight parameters (e.g., airspeed, density, coefficient of viscosity) at the two Mach numbers. The values of $\lambda_{T}$ and $M$ were $(0.0944,0.324)$ and $(0.0939,0.512)$. These combinations of $\lambda_{T}$ and $M$ were within the domain of the models specified in Equation (10) for the DGB parachutes. The static coefficients thus calculated are shown in Figure 13. The differences between the two flight conditions are principally due to the Mach number. Because the total porosity is nearly the same for these two flight conditions, total porosity is not the primary source of the differences between the curves in Figure 13. Reconstructed values of the static coefficients for the MSL descent on Mars are not available; there was insufficient data to reconstruct the static coefficients. Thus, a validation comparison cannot be conducted for the modeled static coefficients shown in Figure 13. 

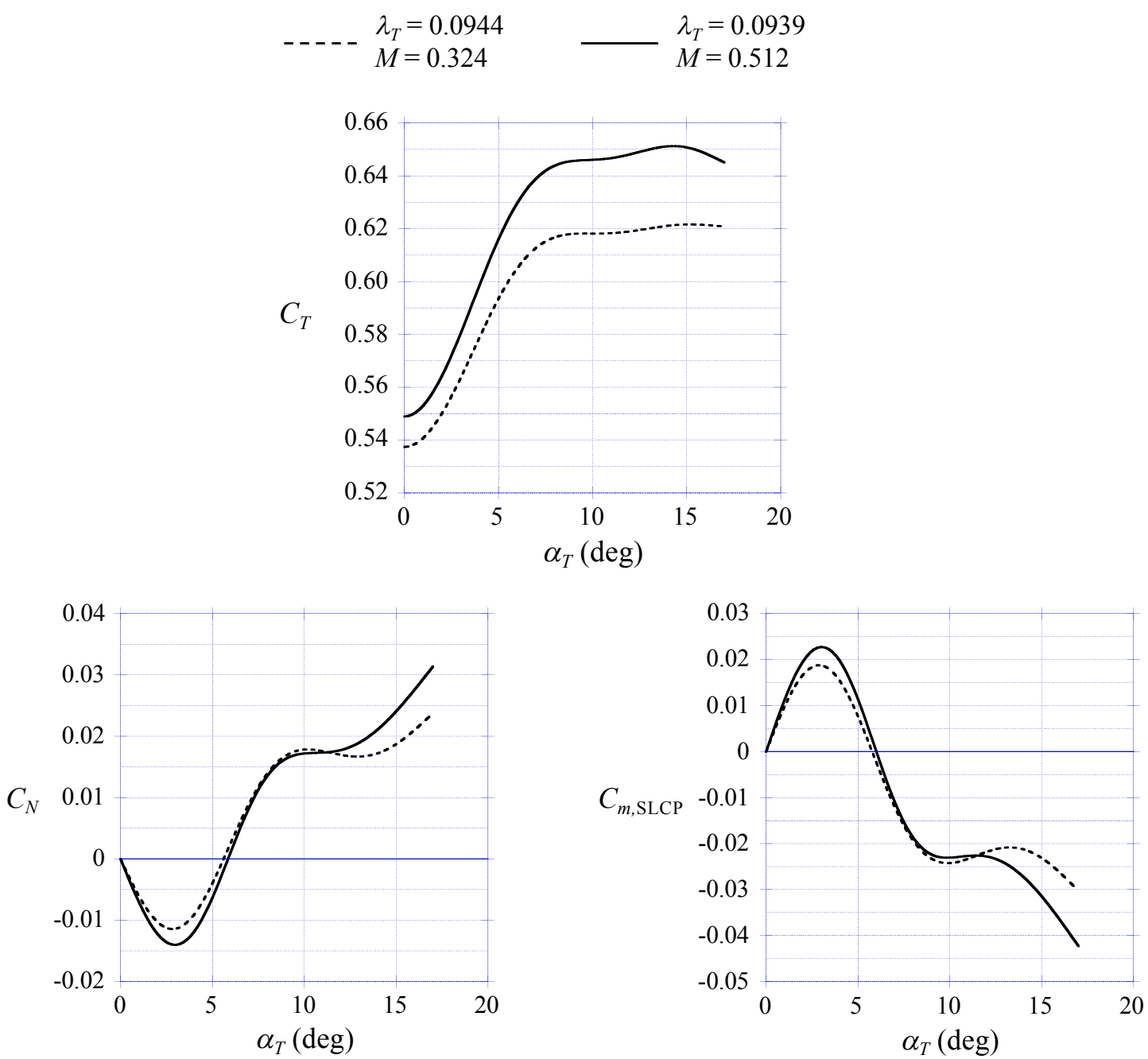

Figure 14. Modeled static coefficients for MSL during terminal descent.

\section{Concluding Remarks}

Models were presented for the aerodynamic coefficients (i.e., $C_{D}, C_{\text {Tot }}, C_{T}, C_{N}$, and $C_{m, \mathrm{SLCP}}$ ) of SSRS and DGB parachutes as functions of total porosity, $\lambda_{T}$, Mach number, $M$, and total angle of attack, $\alpha_{T}$ (when necessary). The source aerodynamic coefficients data for creating these models were obtained during the wind tunnel test described in Reference 2. The total porosity for these parachutes was calculated using the fabric permeability test data presented in Reference 3. Although the models are simple functions of $\lambda_{T}$ and $M$, they provide good reproductions of the source aerodynamic coefficient data. The $\left(\lambda_{T}, M\right)$ domains of applicability for these models were defined. These domains are applicable to flight operations on Mars.

The models presented herein are not unique - other models could be created from the source data. To make this possible the aerodynamic coefficients source data are presented in Tables 2 and 3 (drag and total force coefficients) and Reference 9 (static coefficients). 
APPENDIX: MODELS FOR THE STATIC COEFFICIENTS

Table A1. Model for $C_{T}$ - SSRS parachute.

\begin{tabular}{|c|c|c|c|c|}
\hline$\alpha_{T}(\mathrm{deg})$ & $a_{0, \alpha_{T}}$ & $a_{1, \alpha_{T}}$ & $a_{2, \alpha_{T}}$ & $a_{12, \alpha_{T}}$ \\
\hline 0.0 & $7.95735 \mathrm{E}-01$ & $-1.66648 \mathrm{E}+00$ & $1.33957 \mathrm{E}-01$ & $-6.30962 \mathrm{E}-01$ \\
\hline 0.2 & $7.95753 \mathrm{E}-01$ & $-1.66624 \mathrm{E}+00$ & $1.34475 \mathrm{E}-01$ & $-6.34325 \mathrm{E}-01$ \\
\hline 0.4 & 7.95804E-01 & $-1.66551 \mathrm{E}+00$ & $1.36025 \mathrm{E}-01$ & $-6.44387 \mathrm{E}-01$ \\
\hline 0.6 & 7.95890E-01 & $-1.66432 \mathrm{E}+00$ & $1.38593 \mathrm{E}-01$ & $-6.61059 \mathrm{E}-01$ \\
\hline 0.8 & $7.96010 \mathrm{E}-01$ & $-1.66268 \mathrm{E}+00$ & $1.42165 \mathrm{E}-01$ & $-6.84244 \mathrm{E}-01$ \\
\hline 1.0 & $7.96165 \mathrm{E}-01$ & $-1.66062 \mathrm{E}+00$ & $1.46726 \mathrm{E}-01$ & $-7.13841 \mathrm{E}-01$ \\
\hline 1.2 & $7.96360 \mathrm{E}-01$ & $-1.65819 \mathrm{E}+00$ & $1.52248 \mathrm{E}-01$ & $-7.49648 \mathrm{E}-01$ \\
\hline 1.4 & $7.96595 \mathrm{E}-01$ & $-1.65543 \mathrm{E}+00$ & $1.58696 \mathrm{E}-01$ & $-7.91418 \mathrm{E}-01$ \\
\hline 1.6 & 7.96871E-01 & $-1.65235 \mathrm{E}+00$ & $1.66037 \mathrm{E}-01$ & $-8.38941 \mathrm{E}-01$ \\
\hline 1.8 & $7.97185 \mathrm{E}-01$ & $-1.64897 \mathrm{E}+00$ & $1.74239 \mathrm{E}-01$ & $-8.92009 \mathrm{E}-01$ \\
\hline 2.0 & 7.97539E-01 & $-1.64532 \mathrm{E}+00$ & $1.83270 \mathrm{E}-01$ & $-9.50413 \mathrm{E}-01$ \\
\hline 2.2 & 7.97927E-01 & $-1.64139 \mathrm{E}+00$ & $1.93100 \mathrm{E}-01$ & $-1.01397 \mathrm{E}+00$ \\
\hline 2.4 & $7.98346 \mathrm{E}-01$ & $-1.63717 \mathrm{E}+00$ & $2.03673 \mathrm{E}-01$ & $-1.08232 \mathrm{E}+00$ \\
\hline 2.6 & 7.98795E-01 & $-1.63271 \mathrm{E}+00$ & $2.14915 \mathrm{E}-01$ & $-1.15497 \mathrm{E}+00$ \\
\hline 2.8 & 7.99277E-01 & $-1.62805 \mathrm{E}+00$ & $2.26748 \mathrm{E}-01$ & $-1.23137 \mathrm{E}+00$ \\
\hline 3.0 & 7.99792E-01 & $-1.62324 \mathrm{E}+00$ & $2.39093 \mathrm{E}-01$ & $-1.31100 \mathrm{E}+00$ \\
\hline 3.2 & $8.00341 \mathrm{E}-01$ & $-1.61832 \mathrm{E}+00$ & $2.51871 \mathrm{E}-01$ & $-1.39331 \mathrm{E}+00$ \\
\hline 3.4 & 8.00923E-01 & $-1.61333 \mathrm{E}+00$ & $2.64978 \mathrm{E}-01$ & $-1.47761 \mathrm{E}+00$ \\
\hline 3.6 & $8.01540 \mathrm{E}-01$ & $-1.60834 \mathrm{E}+00$ & $2.78296 \mathrm{E}-01$ & $-1.56307 \mathrm{E}+00$ \\
\hline 3.8 & 8.02194E-01 & $-1.60341 \mathrm{E}+00$ & $2.91703 \mathrm{E}-01$ & $-1.64885 \mathrm{E}+00$ \\
\hline 4.0 & $8.02887 \mathrm{E}-01$ & $-1.59860 \mathrm{E}+00$ & $3.05081 \mathrm{E}-01$ & $-1.73414 \mathrm{E}+00$ \\
\hline 4.2 & 8.03619E-01 & $-1.59399 \mathrm{E}+00$ & $3.18311 \mathrm{E}-01$ & $-1.81811 \mathrm{E}+00$ \\
\hline 4.4 & 8.04389E-01 & $-1.58960 \mathrm{E}+00$ & $3.31274 \mathrm{E}-01$ & $-1.89996 \mathrm{E}+00$ \\
\hline 4.6 & $8.05194 \mathrm{E}-01$ & $-1.58547 \mathrm{E}+00$ & $3.43852 \mathrm{E}-01$ & $-1.97888 \mathrm{E}+00$ \\
\hline 4.8 & $8.06029 \mathrm{E}-01$ & $-1.58162 \mathrm{E}+00$ & $3.55926 \mathrm{E}-01$ & $-2.05408 \mathrm{E}+00$ \\
\hline 5.0 & 8.06893E-01 & $-1.57809 \mathrm{E}+00$ & $3.67379 \mathrm{E}-01$ & $-2.12474 \mathrm{E}+00$ \\
\hline 5.2 & $8.07780 \mathrm{E}-01$ & $-1.57490 \mathrm{E}+00$ & $3.78106 \mathrm{E}-01$ & $-2.19018 \mathrm{E}+00$ \\
\hline 5.4 & $8.08683 \mathrm{E}-01$ & $-1.57204 \mathrm{E}+00$ & $3.88056 \mathrm{E}-01$ & $-2.25005 \mathrm{E}+00$ \\
\hline 5.6 & 8.09591E-01 & $-1.56951 \mathrm{E}+00$ & 3.97194E-01 & $-2.30413 \mathrm{E}+00$ \\
\hline 5.8 & $8.10495 \mathrm{E}-01$ & $-1.56728 \mathrm{E}+00$ & 4.05482E-01 & $-2.35221 \mathrm{E}+00$ \\
\hline 6.0 & $8.11387 \mathrm{E}-01$ & $-1.56533 \mathrm{E}+00$ & $4.12885 \mathrm{E}-01$ & $-2.39407 \mathrm{E}+00$ \\
\hline 6.2 & $8.12258 \mathrm{E}-01$ & $-1.56367 \mathrm{E}+00$ & 4.19371E-01 & $-2.42953 \mathrm{E}+00$ \\
\hline 6.4 & $8.13100 \mathrm{E}-01$ & $-1.56226 \mathrm{E}+00$ & 4.24951E-01 & $-2.45868 \mathrm{E}+00$ \\
\hline 6.6 & $8.13902 \mathrm{E}-01$ & $-1.56107 \mathrm{E}+00$ & $4.29658 \mathrm{E}-01$ & $-2.48180 \mathrm{E}+00$ \\
\hline 6.8 & $8.14652 \mathrm{E}-01$ & $-1.56003 \mathrm{E}+00$ & $4.33521 \mathrm{E}-01$ & $-2.49912 \mathrm{E}+00$ \\
\hline 7.0 & $8.15337 \mathrm{E}-01$ & $-1.55911 \mathrm{E}+00$ & $4.36571 \mathrm{E}-01$ & $-2.51092 \mathrm{E}+00$ \\
\hline 7.2 & 8.15949E-01 & $-1.55825 \mathrm{E}+00$ & 4.38845E-01 & $-2.51746 \mathrm{E}+00$ \\
\hline 7.4 & $8.16480 \mathrm{E}-01$ & $-1.55743 \mathrm{E}+00$ & $4.40408 \mathrm{E}-01$ & $-2.51923 \mathrm{E}+00$ \\
\hline 7.6 & $8.16923 \mathrm{E}-01$ & $-1.55659 \mathrm{E}+00$ & 4.41339E-01 & $-2.51683 \mathrm{E}+00$ \\
\hline 7.8 & $8.17267 \mathrm{E}-01$ & $-1.55568 \mathrm{E}+00$ & 4.41720E-01 & $-2.51085 \mathrm{E}+00$ \\
\hline 8.0 & $8.17505 \mathrm{E}-01$ & $-1.55463 \mathrm{E}+00$ & 4.41632E-01 & $-2.50189 \mathrm{E}+00$ \\
\hline 8.2 & $8.17627 \mathrm{E}-01$ & $-1.55338 \mathrm{E}+00$ & 4.41163E-01 & $-2.49061 \mathrm{E}+00$ \\
\hline 8.4 & 8.17629E-01 & $-1.55188 \mathrm{E}+00$ & 4.40411E-01 & $-2.47772 \mathrm{E}+00$ \\
\hline 8.6 & 8.17509E-01 & $-1.55009 \mathrm{E}+00$ & 4.39467E-01 & $-2.46390 \mathrm{E}+00$ \\
\hline 8.8 & $8.17265 \mathrm{E}-01$ & $-1.54796 \mathrm{E}+00$ & 4.38426E-01 & $-2.44983 \mathrm{E}+00$ \\
\hline
\end{tabular}

Continued

16

American Institute of Aeronautics and Astronautics 
Table A1. Concluded.

\begin{tabular}{|c|c|c|c|c|}
\hline$\alpha_{T}(\mathrm{deg})$ & $a_{0, \alpha_{T}}$ & $a_{1, \alpha_{T}}$ & $a_{2, \alpha_{T}}$ & $a_{12, \alpha_{T}}$ \\
\hline 9.0 & $8.16894 \mathrm{E}-01$ & $-1.54545 \mathrm{E}+00$ & $4.37380 \mathrm{E}-01$ & $-2.43621 \mathrm{E}+00$ \\
\hline 9.2 & $8.16395 \mathrm{E}-01$ & $-1.54252 \mathrm{E}+00$ & 4.36418E-01 & $-2.42366 \mathrm{E}+00$ \\
\hline 9.4 & $8.15776 \mathrm{E}-01$ & $-1.53919 \mathrm{E}+00$ & $4.35603 \mathrm{E}-01$ & $-2.41266 \mathrm{E}+00$ \\
\hline 9.6 & $8.15044 \mathrm{E}-01$ & $-1.53547 \mathrm{E}+00$ & 4.34992E-01 & $-2.40359 \mathrm{E}+00$ \\
\hline 9.8 & $8.14207 \mathrm{E}-01$ & $-1.53137 \mathrm{E}+00$ & 4.34644E-01 & $-2.39686 \mathrm{E}+00$ \\
\hline 10.0 & $8.13273 \mathrm{E}-01$ & $-1.52691 \mathrm{E}+00$ & 4.34614E-01 & $-2.39290 \mathrm{E}+00$ \\
\hline 10.2 & $8.12251 \mathrm{E}-01$ & $-1.52211 \mathrm{E}+00$ & 4.34949E-01 & $-2.39201 \mathrm{E}+00$ \\
\hline 10.4 & $8.11157 \mathrm{E}-01$ & $-1.51704 \mathrm{E}+00$ & $4.35636 \mathrm{E}-01$ & $-2.39409 \mathrm{E}+00$ \\
\hline 10.6 & $8.10011 \mathrm{E}-01$ & $-1.51182 \mathrm{E}+00$ & $4.36646 \mathrm{E}-01$ & $-2.39891 \mathrm{E}+00$ \\
\hline 10.8 & $8.08831 \mathrm{E}-01$ & $-1.50653 \mathrm{E}+00$ & $4.37950 \mathrm{E}-01$ & $-2.40624 \mathrm{E}+00$ \\
\hline 11.0 & $8.07638 \mathrm{E}-01$ & $-1.50128 \mathrm{E}+00$ & $4.39518 \mathrm{E}-01$ & $-2.41585 \mathrm{E}+00$ \\
\hline 11.2 & $8.06448 \mathrm{E}-01$ & $-1.49615 \mathrm{E}+00$ & $4.41321 \mathrm{E}-01$ & $-2.42751 \mathrm{E}+00$ \\
\hline 11.4 & $8.05278 \mathrm{E}-01$ & $-1.49124 \mathrm{E}+00$ & 4.43322E-01 & $-2.44094 \mathrm{E}+00$ \\
\hline 11.6 & $8.04143 \mathrm{E}-01$ & $-1.48663 \mathrm{E}+00$ & $4.45478 \mathrm{E}-01$ & $-2.45582 \mathrm{E}+00$ \\
\hline 11.8 & $8.03060 \mathrm{E}-01$ & $-1.48243 \mathrm{E}+00$ & 4.47745E-01 & $-2.47182 \mathrm{E}+00$ \\
\hline 12.0 & $8.02044 \mathrm{E}-01$ & $-1.47871 \mathrm{E}+00$ & $4.50080 \mathrm{E}-01$ & $-2.48861 \mathrm{E}+00$ \\
\hline 12.2 & $8.01112 \mathrm{E}-01$ & $-1.47558 \mathrm{E}+00$ & $4.52439 \mathrm{E}-01$ & $-2.50587 \mathrm{E}+00$ \\
\hline 12.4 & $8.00272 \mathrm{E}-01$ & $-1.47308 \mathrm{E}+00$ & 4.54794E-01 & $-2.52337 \mathrm{E}+00$ \\
\hline 12.6 & $7.99533 \mathrm{E}-01$ & $-1.47129 \mathrm{E}+00$ & $4.57115 \mathrm{E}-01$ & $-2.54091 \mathrm{E}+00$ \\
\hline 12.8 & $7.98904 \mathrm{E}-01$ & $-1.47027 \mathrm{E}+00$ & $4.59373 \mathrm{E}-01$ & $-2.55825 \mathrm{E}+00$ \\
\hline 13.0 & 7.98394E-01 & $-1.47009 \mathrm{E}+00$ & 4.61539E-01 & $-2.57516 \mathrm{E}+00$ \\
\hline 13.2 & $7.98011 \mathrm{E}-01$ & $-1.47081 \mathrm{E}+00$ & $4.63588 \mathrm{E}-01$ & $-2.59143 \mathrm{E}+00$ \\
\hline 13.4 & 7.97754E-01 & $-1.47244 \mathrm{E}+00$ & $4.65515 \mathrm{E}-01$ & $-2.60703 \mathrm{E}+00$ \\
\hline 13.6 & $7.97622 \mathrm{E}-01$ & $-1.47498 \mathrm{E}+00$ & 4.67324E-01 & $-2.62197 \mathrm{E}+00$ \\
\hline 13.8 & $7.97613 \mathrm{E}-01$ & $-1.47843 \mathrm{E}+00$ & 4.69014E-01 & $-2.63624 \mathrm{E}+00$ \\
\hline 14.0 & $7.97725 \mathrm{E}-01$ & $-1.48279 \mathrm{E}+00$ & 4.70588E-01 & $-2.64985 \mathrm{E}+00$ \\
\hline 14.2 & $7.97955 \mathrm{E}-01$ & $-1.48807 \mathrm{E}+00$ & 4.72051E-01 & $-2.66282 \mathrm{E}+00$ \\
\hline 14.4 & $7.98298 \mathrm{E}-01$ & $-1.49421 \mathrm{E}+00$ & 4.73414E-01 & $-2.67523 \mathrm{E}+00$ \\
\hline 14.6 & 7.98744E-01 & $-1.50118 \mathrm{E}+00$ & 4.74697E-01 & $-2.68720 \mathrm{E}+00$ \\
\hline 14.8 & 7.99287E-01 & $-1.50894 \mathrm{E}+00$ & $4.75915 \mathrm{E}-01$ & $-2.69883 \mathrm{E}+00$ \\
\hline 15.0 & 7.99917E-01 & $-1.51742 \mathrm{E}+00$ & 4.77084E-01 & $-2.71024 \mathrm{E}+00$ \\
\hline 15.2 & $8.00627 \mathrm{E}-01$ & $-1.52660 \mathrm{E}+00$ & $4.78221 \mathrm{E}-01$ & $-2.72153 \mathrm{E}+00$ \\
\hline 15.4 & $8.01410 \mathrm{E}-01$ & $-1.53641 \mathrm{E}+00$ & 4.79334E-01 & $-2.73273 \mathrm{E}+00$ \\
\hline 15.6 & $8.02256 \mathrm{E}-01$ & $-1.54678 \mathrm{E}+00$ & $4.80430 \mathrm{E}-01$ & $-2.74388 \mathrm{E}+00$ \\
\hline 15.8 & $8.03154 \mathrm{E}-01$ & $-1.55763 \mathrm{E}+00$ & $4.81517 \mathrm{E}-01$ & $-2.75503 \mathrm{E}+00$ \\
\hline 16.0 & $8.04096 \mathrm{E}-01$ & $-1.56887 \mathrm{E}+00$ & $4.82602 \mathrm{E}-01$ & $-2.76623 \mathrm{E}+00$ \\
\hline 16.2 & $8.05071 \mathrm{E}-01$ & $-1.58043 \mathrm{E}+00$ & 4.83694E-01 & $-2.77751 \mathrm{E}+00$ \\
\hline 16.4 & $8.06073 \mathrm{E}-01$ & $-1.59224 \mathrm{E}+00$ & 4.84792E-01 & $-2.78888 \mathrm{E}+00$ \\
\hline 16.6 & $8.07096 \mathrm{E}-01$ & $-1.60424 \mathrm{E}+00$ & $4.85895 \mathrm{E}-01$ & $-2.80031 \mathrm{E}+00$ \\
\hline 16.8 & $8.08132 \mathrm{E}-01$ & $-1.61638 \mathrm{E}+00$ & $4.87002 \mathrm{E}-01$ & $-2.81178 \mathrm{E}+00$ \\
\hline 17.0 & $8.09176 \mathrm{E}-01$ & $-1.62859 \mathrm{E}+00$ & $4.88111 \mathrm{E}-01$ & $-2.82328 \mathrm{E}+00$ \\
\hline
\end{tabular}


Table A2. Model for $C_{N}$ - SSRS parachute.

\begin{tabular}{|c|c|c|c|c|}
\hline$\alpha_{T}(\mathrm{deg})$ & $a_{0, \alpha_{T}}$ & $a_{1, \alpha_{T}}$ & $a_{2, \alpha_{T}}$ & $a_{12, \alpha_{T}}$ \\
\hline 0.0 & $0.00000 \mathrm{E}+00$ & $0.00000 \mathrm{E}+00$ & $0.00000 \mathrm{E}+00$ & $0.00000 \mathrm{E}+00$ \\
\hline 0.2 & $-3.66433 \mathrm{E}-03$ & $1.79912 \mathrm{E}-02$ & $-4.85078 \mathrm{E}-03$ & $3.87085 \mathrm{E}-02$ \\
\hline 0.4 & $-7.36743 \mathrm{E}-03$ & $3.63673 \mathrm{E}-02$ & $-9.51399 \mathrm{E}-03$ & 7.60009E-02 \\
\hline 0.6 & $-1.11469 \mathrm{E}-02$ & $5.55026 \mathrm{E}-02$ & $-1.38049 \mathrm{E}-02$ & $1.10486 \mathrm{E}-01$ \\
\hline 0.8 & $-1.50404 \mathrm{E}-02$ & $7.57705 \mathrm{E}-02$ & $-1.75389 \mathrm{E}-02$ & $1.40776 \mathrm{E}-01$ \\
\hline 1.0 & $-1.90849 \mathrm{E}-02$ & $9.75410 \mathrm{E}-02$ & $-2.05323 \mathrm{E}-02$ & 1.65489E-01 \\
\hline 1.2 & $-2.33069 \mathrm{E}-02$ & $1.21097 \mathrm{E}-01$ & $-2.26328 \mathrm{E}-02$ & $1.83491 \mathrm{E}-01$ \\
\hline 1.4 & $-2.77067 \mathrm{E}-02$ & $1.46522 \mathrm{E}-01$ & $-2.37700 \mathrm{E}-02$ & $1.94259 \mathrm{E}-01$ \\
\hline 1.6 & $-3.22783 \mathrm{E}-02$ & $1.73849 \mathrm{E}-01$ & $-2.38924 \mathrm{E}-02$ & $1.97411 \mathrm{E}-01$ \\
\hline 1.8 & $-3.70157 \mathrm{E}-02$ & $2.03113 \mathrm{E}-01$ & $-2.29484 \mathrm{E}-02$ & $1.92568 \mathrm{E}-01$ \\
\hline 2.0 & $-4.19129 \mathrm{E}-02$ & $2.34349 \mathrm{E}-01$ & $-2.08866 \mathrm{E}-02$ & $1.79350 \mathrm{E}-01$ \\
\hline 2.2 & $-4.69593 \mathrm{E}-02$ & $2.67551 \mathrm{E}-01$ & $-1.76726 \mathrm{E}-02$ & $1.57498 \mathrm{E}-01$ \\
\hline 2.4 & $-5.21133 \mathrm{E}-02$ & $3.02464 \mathrm{E}-01$ & $-1.33749 \mathrm{E}-02$ & $1.27535 \mathrm{E}-01$ \\
\hline 2.6 & $-5.73178 \mathrm{E}-02$ & $3.38699 \mathrm{E}-01$ & $-8.11306 \mathrm{E}-03$ & $9.03771 \mathrm{E}-02$ \\
\hline 2.8 & $-6.25148 \mathrm{E}-02$ & $3.75866 \mathrm{E}-01$ & $-2.00818 \mathrm{E}-03$ & 4.69557E-02 \\
\hline 3.0 & $-6.76465 \mathrm{E}-02$ & $4.13570 \mathrm{E}-01$ & $4.81810 \mathrm{E}-03$ & $-1.79323 \mathrm{E}-03$ \\
\hline 3.2 & $-7.26529 \mathrm{E}-02$ & 4.51394E-01 & $1.22362 \mathrm{E}-02$ & $-5.48712 \mathrm{E}-02$ \\
\hline 3.4 & $-7.74733 \mathrm{E}-02$ & 4.88887E-01 & $2.00806 \mathrm{E}-02$ & $-1.11036 \mathrm{E}-01$ \\
\hline 3.6 & $-8.20387 \mathrm{E}-02$ & $5.25517 \mathrm{E}-01$ & $2.81537 \mathrm{E}-02$ & $-1.68785 \mathrm{E}-01$ \\
\hline 3.8 & $-8.62795 \mathrm{E}-02$ & $5.60747 \mathrm{E}-01$ & $3.62564 \mathrm{E}-02$ & $-2.26605 \mathrm{E}-01$ \\
\hline 4.0 & $-9.01262 \mathrm{E}-02$ & $5.94041 \mathrm{E}-01$ & 4.41899E-02 & $-2.82984 \mathrm{E}-01$ \\
\hline 4.2 & $-9.35173 \mathrm{E}-02$ & $6.24923 \mathrm{E}-01$ & $5.17686 \mathrm{E}-02$ & $-3.36533 \mathrm{E}-01$ \\
\hline 4.4 & $-9.64258 \mathrm{E}-02$ & $6.53160 \mathrm{E}-01$ & 5.88619E-02 & $-3.86330 \mathrm{E}-01$ \\
\hline 4.6 & $-9.88299 \mathrm{E}-02$ & $6.78536 \mathrm{E}-01$ & $6.53462 \mathrm{E}-02$ & $-4.31485 \mathrm{E}-01$ \\
\hline 4.8 & $-1.00707 \mathrm{E}-01$ & 7.00829E-01 & 7.10972E-02 & $-4.71101 \mathrm{E}-01$ \\
\hline 5.0 & $-1.02035 \mathrm{E}-01$ & 7.19815E-01 & 7.59904E-02 & $-5.04279 \mathrm{E}-01$ \\
\hline 5.2 & $-1.02797 \mathrm{E}-01$ & 7.35295E-01 & 7.99146E-02 & $-5.30213 \mathrm{E}-01$ \\
\hline 5.4 & $-1.03030 \mathrm{E}-01$ & 7.47444E-01 & 8.28767E-02 & $-5.48971 \mathrm{E}-01$ \\
\hline 5.6 & $-1.02791 \mathrm{E}-01$ & 7.56549E-01 & 8.49258E-02 & $-5.60920 \mathrm{E}-01$ \\
\hline 5.8 & $-1.02138 \mathrm{E}-01$ & $7.62895 \mathrm{E}-01$ & $8.61105 \mathrm{E}-02$ & $-5.66420 \mathrm{E}-01$ \\
\hline 6.0 & $-1.01126 \mathrm{E}-01$ & 7.66766E-01 & 8.64794E-02 & $-5.65831 \mathrm{E}-01$ \\
\hline 6.2 & $-9.98113 \mathrm{E}-02$ & 7.68452E-01 & $8.60852 \mathrm{E}-02$ & $-5.59541 \mathrm{E}-01$ \\
\hline 6.4 & $-9.82589 \mathrm{E}-02$ & $7.68310 \mathrm{E}-01$ & 8.50104E-02 & $-5.48148 \mathrm{E}-01$ \\
\hline 6.6 & $-9.65376 \mathrm{E}-02$ & 7.66742E-01 & $8.33503 \mathrm{E}-02$ & $-5.32350 \mathrm{E}-01$ \\
\hline 6.8 & $-9.47166 \mathrm{E}-02$ & 7.64157E-01 & $8.12005 \mathrm{E}-02$ & $-5.12848 \mathrm{E}-01$ \\
\hline 7.0 & $-9.28654 \mathrm{E}-02$ & $7.60960 \mathrm{E}-01$ & $7.86569 \mathrm{E}-02$ & $-4.90343 \mathrm{E}-01$ \\
\hline 7.2 & $-9.10470 \mathrm{E}-02$ & $7.57517 \mathrm{E}-01$ & $7.58075 \mathrm{E}-02$ & $-4.65474 \mathrm{E}-01$ \\
\hline 7.4 & $-8.93008 \mathrm{E}-02$ & $7.54050 \mathrm{E}-01$ & 7.27099E-02 & $-4.38625 \mathrm{E}-01$ \\
\hline 7.6 & $-8.76647 \mathrm{E}-02$ & 7.50797E-01 & $6.94206 \mathrm{E}-02$ & $-4.10187 \mathrm{E}-01$ \\
\hline 7.8 & $-8.61770 \mathrm{E}-02$ & 7.48002E-01 & 6.59968E-02 & $-3.80560 \mathrm{E}-01$ \\
\hline 8.0 & $-8.48760 \mathrm{E}-02$ & $7.45906 \mathrm{E}-01$ & $6.24958 \mathrm{E}-02$ & $-3.50145 \mathrm{E}-01$ \\
\hline 8.2 & $-8.37954 \mathrm{E}-02$ & 7.44731E-01 & $5.89758 \mathrm{E}-02$ & $-3.19358 \mathrm{E}-01$ \\
\hline 8.4 & $-8.29386 \mathrm{E}-02$ & $7.44511 \mathrm{E}-01$ & $5.54553 \mathrm{E}-02$ & $-2.88322 \mathrm{E}-01$ \\
\hline 8.6 & $-8.23012 \mathrm{E}-02$ & 7.45243E-01 & $5.19328 \mathrm{E}-02$ & $-2.57014 \mathrm{E}-01$ \\
\hline 8.8 & $-8.18792 \mathrm{E}-02$ & 7.46929E-01 & 4.84075E-02 & $-2.25416 \mathrm{E}-01$ \\
\hline
\end{tabular}

Continued

18

American Institute of Aeronautics and Astronautics 
Table A2. Concluded.

\begin{tabular}{|c|c|c|c|c|}
\hline$\alpha_{T}(\mathrm{deg})$ & $a_{0, \alpha_{T}}$ & $a_{1, \alpha_{T}}$ & $a_{2, \alpha_{T}}$ & $a_{12, \alpha_{T}}$ \\
\hline 9.0 & $-8.16686 \mathrm{E}-02$ & $7.49571 \mathrm{E}-01$ & $4.48788 \mathrm{E}-02$ & $-1.93514 \mathrm{E}-01$ \\
\hline 9.2 & $-8.16616 \mathrm{E}-02$ & $7.53145 \mathrm{E}-01$ & $4.13413 \mathrm{E}-02$ & $-1.61260 \mathrm{E}-01$ \\
\hline 9.4 & $-8.18320 \mathrm{E}-02$ & $7.57509 \mathrm{E}-01$ & $3.77661 \mathrm{E}-02$ & $-1.28425 \mathrm{E}-01$ \\
\hline 9.6 & $-8.21512 \mathrm{E}-02$ & $7.62511 \mathrm{E}-01$ & $3.41208 \mathrm{E}-02$ & $-9.47648 \mathrm{E}-02$ \\
\hline 9.8 & $-8.25912 \mathrm{E}-02$ & 7.68004E-01 & $3.03735 \mathrm{E}-02$ & $-6.00413 \mathrm{E}-02$ \\
\hline 10.0 & $-8.31237 \mathrm{E}-02$ & $7.73843 \mathrm{E}-01$ & $2.64926 \mathrm{E}-02$ & $-2.40166 \mathrm{E}-02$ \\
\hline 10.2 & $-8.37225 \mathrm{E}-02$ & 7.79891E-01 & $2.24518 \mathrm{E}-02$ & $1.35041 \mathrm{E}-02$ \\
\hline 10.4 & $-8.43710 \mathrm{E}-02$ & $7.86079 \mathrm{E}-01$ & $1.82505 \mathrm{E}-02$ & $5.25017 \mathrm{E}-02$ \\
\hline 10.6 & $-8.50544 \mathrm{E}-02$ & 7.92342E-01 & $1.38940 \mathrm{E}-02$ & $9.29170 \mathrm{E}-02$ \\
\hline 10.8 & $-8.57574 \mathrm{E}-02$ & 7.98612E-01 & $9.38673 \mathrm{E}-03$ & $1.34697 \mathrm{E}-01$ \\
\hline 11.0 & $-8.64647 \mathrm{E}-02$ & $8.04821 \mathrm{E}-01$ & 4.73337E-03 & $1.77788 \mathrm{E}-01$ \\
\hline 11.2 & $-8.71638 \mathrm{E}-02$ & $8.10917 \mathrm{E}-01$ & $-5.73920 \mathrm{E}-05$ & $2.22107 \mathrm{E}-01$ \\
\hline 11.4 & $-8.78547 \mathrm{E}-02$ & $8.16934 \mathrm{E}-01$ & $-4.95887 \mathrm{E}-03$ & $2.67430 \mathrm{E}-01$ \\
\hline 11.6 & $-8.85401 \mathrm{E}-02$ & $8.22914 \mathrm{E}-01$ & $-9.94226 \mathrm{E}-03$ & $3.13521 \mathrm{E}-01$ \\
\hline 11.8 & $-8.92220 \mathrm{E}-02$ & $8.28896 \mathrm{E}-01$ & $-1.49794 \mathrm{E}-02$ & $3.60150 \mathrm{E}-01$ \\
\hline 12.0 & $-8.99025 \mathrm{E}-02$ & $8.34921 \mathrm{E}-01$ & $-2.00422 \mathrm{E}-02$ & $4.07088 \mathrm{E}-01$ \\
\hline 12.2 & $-9.05843 \mathrm{E}-02$ & $8.41031 \mathrm{E}-01$ & $-2.51045 \mathrm{E}-02$ & $4.54120 \mathrm{E}-01$ \\
\hline 12.4 & $-9.12754 \mathrm{E}-02$ & $8.47299 \mathrm{E}-01$ & $-3.01439 \mathrm{E}-02$ & $5.01066 \mathrm{E}-01$ \\
\hline 12.6 & $-9.19842 \mathrm{E}-02$ & $8.53796 \mathrm{E}-01$ & $-3.51417 \mathrm{E}-02$ & $5.47786 \mathrm{E}-01$ \\
\hline 12.8 & $-9.27184 \mathrm{E}-02$ & $8.60585 \mathrm{E}-01$ & $-4.00801 \mathrm{E}-02$ & $5.94147 \mathrm{E}-01$ \\
\hline 13.0 & $-9.34860 \mathrm{E}-02$ & $8.67731 \mathrm{E}-01$ & $-4.49410 \mathrm{E}-02$ & $6.40019 \mathrm{E}-01$ \\
\hline 13.2 & $-9.42945 \mathrm{E}-02$ & $8.75295 \mathrm{E}-01$ & $-4.97085 \mathrm{E}-02$ & $6.85282 \mathrm{E}-01$ \\
\hline 13.4 & $-9.51491 \mathrm{E}-02$ & $8.83320 \mathrm{E}-01$ & $-5.43819 \mathrm{E}-02$ & $7.29938 \mathrm{E}-01$ \\
\hline 13.6 & $-9.60528 \mathrm{E}-02$ & $8.91833 \mathrm{E}-01$ & $-5.89690 \mathrm{E}-02$ & $7.74056 \mathrm{E}-01$ \\
\hline 13.8 & $-9.70089 \mathrm{E}-02$ & $9.00858 \mathrm{E}-01$ & $-6.34776 \mathrm{E}-02$ & $8.17709 \mathrm{E}-01$ \\
\hline 14.0 & $-9.80203 \mathrm{E}-02$ & $9.10421 \mathrm{E}-01$ & $-6.79158 \mathrm{E}-02$ & 8.60969E-01 \\
\hline 14.2 & $-9.90893 \mathrm{E}-02$ & $9.20540 \mathrm{E}-01$ & $-7.22935 \mathrm{E}-02$ & $9.03920 \mathrm{E}-01$ \\
\hline 14.4 & $-1.00214 \mathrm{E}-01$ & $9.31200 \mathrm{E}-01$ & $-7.66289 \mathrm{E}-02$ & $9.46710 \mathrm{E}-01$ \\
\hline 14.6 & $-1.01390 \mathrm{E}-01$ & $9.42375 \mathrm{E}-01$ & $-8.09436 \mathrm{E}-02$ & $9.89505 \mathrm{E}-01$ \\
\hline 14.8 & $-1.02614 \mathrm{E}-01$ & $9.54037 \mathrm{E}-01$ & $-8.52589 \mathrm{E}-02$ & $1.03247 \mathrm{E}+00$ \\
\hline 15.0 & $-1.03883 \mathrm{E}-01$ & $9.66160 \mathrm{E}-01$ & $-8.95962 \mathrm{E}-02$ & $1.07579 \mathrm{E}+0 \mathrm{C}$ \\
\hline 15.2 & $-1.05193 \mathrm{E}-01$ & $9.78716 \mathrm{E}-01$ & $-9.39737 \mathrm{E}-02$ & $1.11958 \mathrm{E}+00$ \\
\hline 15.4 & $-1.06540 \mathrm{E}-01$ & $9.91665 \mathrm{E}-01$ & $-9.83973 \mathrm{E}-02$ & $1.16389 \mathrm{E}+00$ \\
\hline 15.6 & $-1.07918 \mathrm{E}-01$ & $1.00495 \mathrm{E}+00$ & $-1.02868 \mathrm{E}-01$ & $1.20871 \mathrm{E}+0 \mathrm{C}$ \\
\hline 15.8 & $-1.09321 \mathrm{E}-01$ & $1.01853 \mathrm{E}+00$ & $-1.07388 \mathrm{E}-01$ & $1.25403 \mathrm{E}+00$ \\
\hline 16.0 & $-1.10744 \mathrm{E}-01$ & $1.03233 \mathrm{E}+00$ & $-1.11959 \mathrm{E}-01$ & $1.29985 \mathrm{E}+0 \mathrm{C}$ \\
\hline 16.2 & $-1.12182 \mathrm{E}-01$ & $1.04631 \mathrm{E}+00$ & $-1.16580 \mathrm{E}-01$ & $1.34615 \mathrm{E}+00$ \\
\hline 16.4 & $-1.13631 \mathrm{E}-01$ & $1.06044 \mathrm{E}+00$ & $-1.21245 \mathrm{E}-01$ & $1.39286 \mathrm{E}+00$ \\
\hline 16.6 & $-1.15089 \mathrm{E}-01$ & $1.07466 \mathrm{E}+00$ & $-1.25943 \mathrm{E}-01$ & $1.43989 \mathrm{E}+00$ \\
\hline 16.8 & $-1.16552 \mathrm{E}-01$ & $1.08896 \mathrm{E}+00$ & $-1.30666 \mathrm{E}-01$ & $1.48714 \mathrm{E}+00$ \\
\hline 17.0 & $-1.18019 \mathrm{E}-01$ & $1.10330 \mathrm{E}+00$ & $-1.35402 \mathrm{E}-01$ & $1.53452 \mathrm{E}+0 \mathrm{C}$ \\
\hline
\end{tabular}


Table A3. Model for $C_{m, \mathrm{SLCP}}$ - SSRS parachute.

\begin{tabular}{|c|c|c|c|c|}
\hline$\alpha_{T}(\operatorname{deg})$ & $a_{0, \alpha_{T}}$ & $a_{1, \alpha_{T}}$ & $a_{2, \alpha_{T}}$ & $a_{12, \alpha_{T}}$ \\
\hline 0.0 & $0.00000 \mathrm{E}+00$ & $0.00000 \mathrm{E}+00$ & $0.00000 \mathrm{E}+00$ & $0.00000 \mathrm{E}+00$ \\
\hline 0.2 & $5.98785 \mathrm{E}-03$ & $-2.98244 \mathrm{E}-02$ & $7.58273 \mathrm{E}-03$ & $-6.31669 \mathrm{E}-02$ \\
\hline 0.4 & $1.20349 \mathrm{E}-02$ & $-6.02444 \mathrm{E}-02$ & $1.48736 \mathrm{E}-02$ & $-1.24103 \mathrm{E}-01$ \\
\hline 0.6 & $1.81987 \mathrm{E}-02$ & $-9.18391 \mathrm{E}-02$ & $2.15850 \mathrm{E}-02$ & $-1.80618 \mathrm{E}-01$ \\
\hline 0.8 & $2.45364 \mathrm{E}-02$ & $-1.25186 \mathrm{E}-01$ & 2.74299E-02 & $-2.30524 \mathrm{E}-01$ \\
\hline 1.0 & $3.11048 \mathrm{E}-02$ & $-1.60858 \mathrm{E}-01$ & 3.21224E-02 & $-2.71646 \mathrm{E}-01$ \\
\hline 1.2 & $3.79438 \mathrm{E}-02$ & $-1.99292 \mathrm{E}-01$ & $3.54259 \mathrm{E}-02$ & $-3.02196 \mathrm{E}-01$ \\
\hline 1.4 & 4.50543E-02 & $-2.40620 \mathrm{E}-01$ & $3.72300 \mathrm{E}-02$ & $-3.21337 \mathrm{E}-01$ \\
\hline 1.6 & $5.24276 \mathrm{E}-02$ & $-2.84904 \mathrm{E}-01$ & $3.74533 \mathrm{E}-02$ & $-3.28452 \mathrm{E}-01$ \\
\hline 1.8 & $6.00554 \mathrm{E}-02$ & $-3.32206 \mathrm{E}-01$ & 3.60144E-02 & $-3.22924 \mathrm{E}-01$ \\
\hline 2.0 & 6.79292E-02 & $-3.82588 \mathrm{E}-01$ & $3.28318 \mathrm{E}-02$ & $-3.04134 \mathrm{E}-01$ \\
\hline 2.2 & 7.60333E-02 & $-4.36052 \mathrm{E}-01$ & $2.78508 \mathrm{E}-02$ & $-2.71661 \mathrm{E}-01$ \\
\hline 2.4 & $8.43053 \mathrm{E}-02$ & $-4.92212 \mathrm{E}-01$ & $2.11764 \mathrm{E}-02$ & $-2.26301 \mathrm{E}-01$ \\
\hline 2.6 & $9.26583 \mathrm{E}-02$ & $-5.50479 \mathrm{E}-01$ & 1.29932E-02 & $-1.69472 \mathrm{E}-01$ \\
\hline 2.8 & $1.01005 \mathrm{E}-01$ & $-6.10260 \mathrm{E}-01$ & $3.48762 \mathrm{E}-03$ & $-1.02608 \mathrm{E}-01$ \\
\hline 3.0 & $1.09257 \mathrm{E}-01$ & $-6.70957 \mathrm{E}-01$ & $-7.15270 \mathrm{E}-03$ & $-2.71537 \mathrm{E}-02$ \\
\hline 3.2 & $1.17323 \mathrm{E}-01$ & $-7.31931 \mathrm{E}-01$ & $-1.87268 \mathrm{E}-02$ & $5.53399 \mathrm{E}-02$ \\
\hline 3.4 & $1.25111 \mathrm{E}-01$ & $-7.92481 \mathrm{E}-01$ & $-3.09765 \mathrm{E}-02$ & $1.42920 \mathrm{E}-01$ \\
\hline 3.6 & $1.32513 \mathrm{E}-01$ & $-8.51785 \mathrm{E}-01$ & $-4.35936 \mathrm{E}-02$ & $2.33232 \mathrm{E}-01$ \\
\hline 3.8 & $1.39423 \mathrm{E}-01$ & $-9.09009 \mathrm{E}-01$ & $-5.62679 \mathrm{E}-02$ & $3.23901 \mathrm{E}-01$ \\
\hline 4.0 & $1.45735 \mathrm{E}-01$ & $-9.63322 \mathrm{E}-01$ & $-6.86894 \mathrm{E}-02$ & $4.12556 \mathrm{E}-01$ \\
\hline 4.2 & $1.51352 \mathrm{E}-01$ & $-1.01398 \mathrm{E}+00$ & $-8.05688 \mathrm{E}-02$ & $4.97016 \mathrm{E}-01$ \\
\hline 4.4 & $1.56233 \mathrm{E}-01$ & $-1.06061 \mathrm{E}+00$ & $-9.16993 \mathrm{E}-02$ & $5.75801 \mathrm{E}-01$ \\
\hline 4.6 & $1.60342 \mathrm{E}-01$ & $-1.10285 \mathrm{E}+00$ & $-1.01885 \mathrm{E}-01$ & $6.47477 \mathrm{E}-01$ \\
\hline 4.8 & $1.63641 \mathrm{E}-01$ & $-1.14034 \mathrm{E}+00$ & $-1.10928 \mathrm{E}-01$ & 7.10598E-01 \\
\hline 5.0 & $1.66095 \mathrm{E}-01$ & $-1.17271 \mathrm{E}+00$ & $-1.18631 \mathrm{E}-01$ & $7.63715 \mathrm{E}-01$ \\
\hline 5.2 & $1.67674 \mathrm{E}-01$ & $-1.19961 \mathrm{E}+00$ & $-1.24817 \mathrm{E}-01$ & $8.05529 \mathrm{E}-01$ \\
\hline 5.4 & $1.68434 \mathrm{E}-01$ & $-1.22130 \mathrm{E}+00$ & $-1.29493 \mathrm{E}-01$ & $8.36101 \mathrm{E}-01$ \\
\hline 5.6 & $1.68459 \mathrm{E}-01$ & $-1.23818 \mathrm{E}+00$ & $-1.32729 \mathrm{E}-01$ & 8.55944E-01 \\
\hline 5.8 & $1.67830 \mathrm{E}-01$ & $-1.25065 \mathrm{E}+00$ & $-1.34595 \mathrm{E}-01$ & $8.65562 \mathrm{E}-01$ \\
\hline 6.0 & $1.66630 \mathrm{E}-01$ & $-1.25910 \mathrm{E}+00$ & $-1.35161 \mathrm{E}-01$ & $8.65456 \mathrm{E}-01$ \\
\hline 6.2 & $1.64943 \mathrm{E}-01$ & $-1.26395 \mathrm{E}+00$ & $-1.34503 \mathrm{E}-01$ & $8.56176 \mathrm{E}-01$ \\
\hline 6.4 & $1.62863 \mathrm{E}-01$ & $-1.26572 \mathrm{E}+00$ & $-1.32745 \mathrm{E}-01$ & 8.38617E-01 \\
\hline 6.6 & $1.60495 \mathrm{E}-01$ & $-1.26502 \mathrm{E}+00$ & $-1.30033 \mathrm{E}-01$ & $8.13840 \mathrm{E}-01$ \\
\hline 6.8 & $1.57943 \mathrm{E}-01$ & $-1.26245 \mathrm{E}+00$ & $-1.26514 \mathrm{E}-01$ & 7.82912E-01 \\
\hline 7.0 & $1.55312 \mathrm{E}-01$ & $-1.25862 \mathrm{E}+00$ & $-1.22333 \mathrm{E}-01$ & $7.46900 \mathrm{E}-01$ \\
\hline 7.2 & $1.52696 \mathrm{E}-01$ & $-1.25409 \mathrm{E}+00$ & $-1.17626 \mathrm{E}-01$ & 7.06777E-01 \\
\hline 7.4 & $1.50158 \mathrm{E}-01$ & $-1.24920 \mathrm{E}+00$ & $-1.12484 \mathrm{E}-01$ & $6.63153 \mathrm{E}-01$ \\
\hline 7.6 & $1.47757 \mathrm{E}-01$ & $-1.24434 \mathrm{E}+00$ & $-1.06998 \mathrm{E}-01$ & $6.16665 \mathrm{E}-01$ \\
\hline 7.8 & $1.45553 \mathrm{E}-01$ & $-1.23990 \mathrm{E}+00$ & $-1.01261 \mathrm{E}-01$ & $5.67966 \mathrm{E}-01$ \\
\hline 8.0 & $1.43609 \mathrm{E}-01$ & $-1.23628 \mathrm{E}+00$ & $-9.53658 \mathrm{E}-02$ & $5.17712 \mathrm{E}-01$ \\
\hline 8.2 & $1.41978 \mathrm{E}-01$ & $-1.23384 \mathrm{E}+00$ & $-8.94064 \mathrm{E}-02$ & $4.66580 \mathrm{E}-01$ \\
\hline 8.4 & $1.40669 \mathrm{E}-01$ & $-1.23267 \mathrm{E}+00$ & $-8.34179 \mathrm{E}-02$ & 4.14813E-01 \\
\hline 8.6 & $1.39680 \mathrm{E}-01$ & $-1.23281 \mathrm{E}+00$ & $-7.74066 \mathrm{E}-02$ & $3.62445 \mathrm{E}-01$ \\
\hline 8.8 & $1.39012 \mathrm{E}-01$ & $-1.23432 \mathrm{E}+00$ & $-7.13795 \mathrm{E}-02$ & $3.09520 \mathrm{E}-01$ \\
\hline
\end{tabular}

Continued 
Table A3. Concluded.

\begin{tabular}{|c|c|c|c|c|}
\hline$\alpha_{T}(\mathrm{deg})$ & $a_{0, \alpha_{T}}$ & $a_{1, \alpha_{T}}$ & $a_{2, \alpha_{T}}$ & $a_{12, \alpha_{T}}$ \\
\hline 9.0 & $1.38662 \mathrm{E}-01$ & $-1.23726 \mathrm{E}+00$ & $-6.53441 \mathrm{E}-02$ & $2.56085 \mathrm{E}-01$ \\
\hline 9.2 & $1.38624 \mathrm{E}-01$ & $-1.24162 \mathrm{E}+00$ & $-5.93003 \mathrm{E}-02$ & $2.02135 \mathrm{E}-01$ \\
\hline 9.4 & $1.38863 \mathrm{E}-01$ & $-1.24723 \mathrm{E}+00$ & $-5.32109 \mathrm{E}-02$ & $1.47379 \mathrm{E}-01$ \\
\hline 9.6 & $1.39340 \mathrm{E}-01$ & $-1.25392 \mathrm{E}+00$ & $-4.70337 \mathrm{E}-02$ & $9.15058 \mathrm{E}-02$ \\
\hline 9.8 & $1.40017 \mathrm{E}-01$ & $-1.26149 \mathrm{E}+00$ & $-4.07273 \mathrm{E}-02$ & $3.42105 \mathrm{E}-02$ \\
\hline 10.0 & $1.40855 \mathrm{E}-01$ & $-1.26978 \mathrm{E}+00$ & $-3.42505 \mathrm{E}-02$ & $-2.48093 \mathrm{E}-02$ \\
\hline 10.2 & $1.41819 \mathrm{E}-01$ & $-1.27860 \mathrm{E}+00$ & $-2.75690 \mathrm{E}-02$ & $-8.58021 \mathrm{E}-02$ \\
\hline 10.4 & $1.42884 \mathrm{E}-01$ & $-1.28787 \mathrm{E}+00$ & $-2.06837 \mathrm{E}-02$ & $-1.48722 \mathrm{E}-01$ \\
\hline 10.6 & $1.44027 \mathrm{E}-01$ & $-1.29748 \mathrm{E}+00$ & $-1.36019 \mathrm{E}-02$ & $-2.13487 \mathrm{E}-01$ \\
\hline 10.8 & $1.45225 \mathrm{E}-01$ & $-1.30733 \mathrm{E}+00$ & $-6.32954 \mathrm{E}-03$ & $-2.80023 \mathrm{E}-01$ \\
\hline 11.0 & $1.46453 \mathrm{E}-01$ & $-1.31729 \mathrm{E}+00$ & $1.12723 \mathrm{E}-03$ & $-3.48258 \mathrm{E}-01$ \\
\hline 11.2 & $1.47692 \mathrm{E}-01$ & $-1.32730 \mathrm{E}+00$ & $8.75638 \mathrm{E}-03$ & $-4.18079 \mathrm{E}-01$ \\
\hline 11.4 & $1.48940 \mathrm{E}-01$ & $-1.33738 \mathrm{E}+00$ & $1.65199 \mathrm{E}-02$ & $-4.89165 \mathrm{E}-01$ \\
\hline 11.6 & $1.50200 \mathrm{E}-01$ & $-1.34757 \mathrm{E}+00$ & $2.43776 \mathrm{E}-02$ & $-5.61190 \mathrm{E}-01$ \\
\hline 11.8 & $1.51470 \mathrm{E}-01$ & $-1.35792 \mathrm{E}+00$ & $3.22903 \mathrm{E}-02$ & $-6.33836 \mathrm{E}-01$ \\
\hline 12.0 & $1.52754 \mathrm{E}-01$ & $-1.36847 \mathrm{E}+00$ & $4.02190 \mathrm{E}-02$ & $-7.06788 \mathrm{E}-01$ \\
\hline 12.2 & $1.54052 \mathrm{E}-01$ & $-1.37925 \mathrm{E}+00$ & 4.81277E-02 & $-7.79753 \mathrm{E}-01$ \\
\hline 12.4 & $1.55375 \mathrm{E}-01$ & $-1.39037 \mathrm{E}+00$ & $5.59864 \mathrm{E}-02$ & $-8.52492 \mathrm{E}-01$ \\
\hline 12.6 & $1.56733 \mathrm{E}-01$ & $-1.40190 \mathrm{E}+00$ & $6.37705 \mathrm{E}-02$ & $-9.24826 \mathrm{E}-01$ \\
\hline 12.8 & $1.58136 \mathrm{E}-01$ & $-1.41394 \mathrm{E}+00$ & $7.14570 \mathrm{E}-02$ & $-9.96591 \mathrm{E}-01$ \\
\hline 13.0 & $1.59594 \mathrm{E}-01$ & $-1.42655 \mathrm{E}+00$ & $7.90225 \mathrm{E}-02$ & $-1.06762 \mathrm{E}+0 \mathrm{c}$ \\
\hline 13.2 & $1.61117 \mathrm{E}-01$ & $-1.43982 \mathrm{E}+00$ & $8.64468 \mathrm{E}-02$ & $-1.13778 \mathrm{E}+0 \mathrm{c}$ \\
\hline 13.4 & $1.62712 \mathrm{E}-01$ & $-1.45380 \mathrm{E}+00$ & $9.37313 \mathrm{E}-02$ & $-1.20708 \mathrm{E}+00$ \\
\hline 13.6 & $1.64383 \mathrm{E}-01$ & $-1.46853 \mathrm{E}+00$ & $1.00890 \mathrm{E}-01$ & $-1.27565 \mathrm{E}+0 \mathrm{C}$ \\
\hline 13.8 & $1.66135 \mathrm{E}-01$ & $-1.48403 \mathrm{E}+00$ & $1.07938 \mathrm{E}-01$ & $-1.34363 \mathrm{E}+00$ \\
\hline 14.0 & $1.67971 \mathrm{E}-01$ & $-1.50036 \mathrm{E}+00$ & $1.14888 \mathrm{E}-01$ & $-1.41114 \mathrm{E}+0 \mathrm{C}$ \\
\hline 14.2 & $1.69895 \mathrm{E}-01$ & $-1.51753 \mathrm{E}+00$ & $1.21759 \mathrm{E}-01$ & $-1.47833 \mathrm{E}+0 \mathrm{C}$ \\
\hline 14.4 & $1.71904 \mathrm{E}-01$ & $-1.53551 \mathrm{E}+00$ & $1.28578 \mathrm{E}-01$ & $-1.54543 \mathrm{E}+00$ \\
\hline 14.6 & $1.73992 \mathrm{E}-01$ & $-1.55428 \mathrm{E}+00$ & $1.35379 \mathrm{E}-01$ & $-1.61269 \mathrm{E}+00$ \\
\hline 14.8 & $1.76155 \mathrm{E}-01$ & $-1.57380 \mathrm{E}+00$ & $1.42195 \mathrm{E}-01$ & $-1.68038 \mathrm{E}+0 \mathrm{C}$ \\
\hline 15.0 & $1.78387 \mathrm{E}-01$ & $-1.59403 \mathrm{E}+00$ & $1.49057 \mathrm{E}-01$ & $-1.74876 \mathrm{E}+0 \mathrm{c}$ \\
\hline 15.2 & $1.80684 \mathrm{E}-01$ & $-1.61493 \mathrm{E}+00$ & $1.55996 \mathrm{E}-01$ & $-1.81803 \mathrm{E}+0 \mathrm{C}$ \\
\hline 15.4 & $1.83039 \mathrm{E}-01$ & $-1.63644 \mathrm{E}+00$ & $1.63017 \mathrm{E}-01$ & $-1.88823 \mathrm{E}+00$ \\
\hline 15.6 & $1.85444 \mathrm{E}-01$ & $-1.65849 \mathrm{E}+00$ & $1.70121 \mathrm{E}-01$ & $-1.95934 \mathrm{E}+00$ \\
\hline 15.8 & $1.87890 \mathrm{E}-01$ & $-1.68098 \mathrm{E}+00$ & $1.77310 \mathrm{E}-01$ & $-2.03132 \mathrm{E}+0 \mathrm{C}$ \\
\hline 16.0 & $1.90368 \mathrm{E}-01$ & $-1.70385 \mathrm{E}+00$ & $1.84584 \mathrm{E}-01$ & $-2.10416 \mathrm{E}+0 \mathrm{C}$ \\
\hline 16.2 & $1.92871 \mathrm{E}-01$ & $-1.72700 \mathrm{E}+00$ & $1.91942 \mathrm{E}-01$ & $-2.17781 \mathrm{E}+0 \mathrm{C}$ \\
\hline 16.4 & $1.95392 \mathrm{E}-01$ & $-1.75038 \mathrm{E}+00$ & $1.99373 \mathrm{E}-01$ & $-2.25215 \mathrm{E}+0 \mathrm{C}$ \\
\hline 16.6 & $1.97928 \mathrm{E}-01$ & $-1.77392 \mathrm{E}+00$ & $2.06859 \mathrm{E}-01$ & $-2.32703 \mathrm{E}+0 \mathrm{C}$ \\
\hline 16.8 & $2.00473 \mathrm{E}-01$ & $-1.79759 \mathrm{E}+00$ & $2.14383 \mathrm{E}-01$ & $-2.40227 \mathrm{E}+0 \mathrm{C}$ \\
\hline 17.0 & $2.03024 \mathrm{E}-01$ & $-1.82132 \mathrm{E}+00$ & $2.21931 \mathrm{E}-01$ & $-2.47773 \mathrm{E}+0 \mathrm{C}$ \\
\hline
\end{tabular}


Table A4. Model for $C_{T}$ - DGB parachute.

\begin{tabular}{|c|c|c|c|c|}
\hline$\alpha_{T}(\operatorname{deg})$ & $a_{0, \alpha_{T}}$ & $a_{1, \alpha_{T}}$ & $a_{2, \alpha_{T}}$ & $a_{12, \alpha_{T}}$ \\
\hline 0.0 & $5.63471 \mathrm{E}-01$ & $-4.81181 \mathrm{E}-01$ & $1.10486 \mathrm{E}-01$ & $-5.38117 \mathrm{E}-01$ \\
\hline 0.2 & $5.63647 \mathrm{E}-01$ & $-4.82110 \mathrm{E}-01$ & $1.10750 \mathrm{E}-01$ & $-5.39177 \mathrm{E}-01$ \\
\hline 0.4 & 5.64154E-01 & $-4.84682 \mathrm{E}-01$ & $1.11555 \mathrm{E}-01$ & $-5.42598 \mathrm{E}-01$ \\
\hline 0.6 & $5.64957 \mathrm{E}-01$ & $-4.88580 \mathrm{E}-01$ & $1.12916 \mathrm{E}-01$ & $-5.48701 \mathrm{E}-01$ \\
\hline 0.8 & $5.66023 \mathrm{E}-01$ & $-4.93486 \mathrm{E}-01$ & $1.14848 \mathrm{E}-01$ & $-5.57808 \mathrm{E}-01$ \\
\hline 1.0 & $5.67317 \mathrm{E}-01$ & $-4.99083 \mathrm{E}-01$ & $1.17366 \mathrm{E}-01$ & $-5.70237 \mathrm{E}-01$ \\
\hline 1.2 & 5.68803E-01 & $-5.05039 \mathrm{E}-01$ & $1.20489 \mathrm{E}-01$ & $-5.86360 \mathrm{E}-01$ \\
\hline 1.4 & $5.70440 \mathrm{E}-01$ & $-5.10975 \mathrm{E}-01$ & $1.24240 \mathrm{E}-01$ & $-6.06610 \mathrm{E}-01$ \\
\hline 1.6 & 5.72184E-01 & $-5.16527 \mathrm{E}-01$ & $1.28624 \mathrm{E}-01$ & $-6.31288 \mathrm{E}-01$ \\
\hline 1.8 & 5.73993E-01 & $-5.21333 \mathrm{E}-01$ & $1.33650 \mathrm{E}-01$ & $-6.60689 \mathrm{E}-01$ \\
\hline 2.0 & 5.75827E-01 & $-5.25034 \mathrm{E}-01$ & $1.39321 \mathrm{E}-01$ & $-6.95105 \mathrm{E}-01$ \\
\hline 2.2 & $5.77646 \mathrm{E}-01$ & $-5.27300 \mathrm{E}-01$ & $1.45638 \mathrm{E}-01$ & $-7.34754 \mathrm{E}-01$ \\
\hline 2.4 & $5.79420 \mathrm{E}-01$ & $-5.27946 \mathrm{E}-01$ & $1.52571 \mathrm{E}-01$ & $-7.79551 \mathrm{E}-01$ \\
\hline 2.6 & 5.81123E-01 & $-5.26817 \mathrm{E}-01$ & $1.60082 \mathrm{E}-01$ & $-8.29342 \mathrm{E}-01$ \\
\hline 2.8 & $5.82728 \mathrm{E}-01$ & $-5.23757 \mathrm{E}-01$ & $1.68135 \mathrm{E}-01$ & $-8.83969 \mathrm{E}-01$ \\
\hline 3.0 & $5.84208 \mathrm{E}-01$ & $-5.18613 \mathrm{E}-01$ & $1.76695 \mathrm{E}-01$ & $-9.43276 \mathrm{E}-01$ \\
\hline 3.2 & $5.85539 \mathrm{E}-01$ & $-5.11275 \mathrm{E}-01$ & $1.85717 \mathrm{E}-01$ & $-1.00702 \mathrm{E}+00$ \\
\hline 3.4 & 5.86719E-01 & $-5.01865 \mathrm{E}-01$ & $1.95120 \mathrm{E}-01$ & $-1.07455 \mathrm{E}+00$ \\
\hline 3.6 & $5.87750 \mathrm{E}-01$ & $-4.90574 \mathrm{E}-01$ & $2.04811 \mathrm{E}-01$ & $-1.14505 \mathrm{E}+00$ \\
\hline 3.8 & $5.88635 \mathrm{E}-01$ & $-4.77598 \mathrm{E}-01$ & $2.14699 \mathrm{E}-01$ & $-1.21773 \mathrm{E}+00$ \\
\hline 4.0 & $5.89376 \mathrm{E}-01$ & $-4.63130 \mathrm{E}-01$ & $2.24690 \mathrm{E}-01$ & $-1.29179 \mathrm{E}+00$ \\
\hline 4.2 & 5.89979E-01 & $-4.47401 \mathrm{E}-01$ & $2.34687 \mathrm{E}-01$ & $-1.36639 \mathrm{E}+00$ \\
\hline 4.4 & $5.90467 \mathrm{E}-01$ & $-4.30793 \mathrm{E}-01$ & $2.44575 \mathrm{E}-01$ & $-1.44042 \mathrm{E}+00$ \\
\hline 4.6 & 5.90863E-01 & $-4.13737 \mathrm{E}-01$ & $2.54230 \mathrm{E}-01$ & $-1.51274 \mathrm{E}+00$ \\
\hline 4.8 & 5.91194E-01 & $-3.96660 \mathrm{E}-01$ & $2.63532 \mathrm{E}-01$ & $-1.58218 \mathrm{E}+00$ \\
\hline 5.0 & $5.91484 \mathrm{E}-01$ & $-3.79992 \mathrm{E}-01$ & $2.72358 \mathrm{E}-01$ & $-1.64758 \mathrm{E}+00$ \\
\hline 5.2 & $5.91766 \mathrm{E}-01$ & $-3.64191 \mathrm{E}-01$ & $2.80582 \mathrm{E}-01$ & $-1.70774 \mathrm{E}+00$ \\
\hline 5.4 & $5.92069 \mathrm{E}-01$ & $-3.49665 \mathrm{E}-01$ & $2.88110 \mathrm{E}-01$ & $-1.76176 \mathrm{E}+00$ \\
\hline 5.6 & $5.92422 \mathrm{E}-01$ & $-3.36746 \mathrm{E}-01$ & $2.94876 \mathrm{E}-01$ & $-1.80898 \mathrm{E}+00$ \\
\hline 5.8 & $5.92849 \mathrm{E}-01$ & $-3.25769 \mathrm{E}-01$ & $3.00816 \mathrm{E}-01$ & $-1.84876 \mathrm{E}+00$ \\
\hline 6.0 & $5.93378 \mathrm{E}-01$ & $-3.17066 \mathrm{E}-01$ & $3.05862 \mathrm{E}-01$ & $-1.88046 \mathrm{E}+00$ \\
\hline 6.2 & $5.94032 \mathrm{E}-01$ & $-3.10934 \mathrm{E}-01$ & $3.09960 \mathrm{E}-01$ & $-1.90353 \mathrm{E}+00$ \\
\hline 6.4 & $5.94824 \mathrm{E}-01$ & $-3.07485 \mathrm{E}-01$ & $3.13105 \mathrm{E}-01$ & $-1.91795 \mathrm{E}+00$ \\
\hline 6.6 & $5.95758 \mathrm{E}-01$ & $-3.06769 \mathrm{E}-01$ & $3.15312 \mathrm{E}-01$ & $-1.92388 \mathrm{E}+00$ \\
\hline 6.8 & $5.96842 \mathrm{E}-01$ & $-3.08837 \mathrm{E}-01$ & $3.16597 \mathrm{E}-01$ & $-1.92147 \mathrm{E}+00$ \\
\hline 7.0 & $5.98081 \mathrm{E}-01$ & $-3.13739 \mathrm{E}-01$ & $3.16974 \mathrm{E}-01$ & $-1.91088 \mathrm{E}+00$ \\
\hline 7.2 & 5.99482E-01 & $-3.21495 \mathrm{E}-01$ & $3.16463 \mathrm{E}-01$ & $-1.89233 \mathrm{E}+00$ \\
\hline 7.4 & $6.01031 \mathrm{E}-01$ & $-3.31930 \mathrm{E}-01$ & $3.15145 \mathrm{E}-01$ & $-1.86662 \mathrm{E}+00$ \\
\hline 7.6 & $6.02713 \mathrm{E}-01$ & $-3.44778 \mathrm{E}-01$ & $3.13124 \mathrm{E}-01$ & $-1.83480 \mathrm{E}+00$ \\
\hline 7.8 & $6.04507 \mathrm{E}-01$ & $-3.59775 \mathrm{E}-01$ & $3.10509 \mathrm{E}-01$ & $-1.79793 \mathrm{E}+00$ \\
\hline 8.0 & $6.06396 \mathrm{E}-01$ & $-3.76658 \mathrm{E}-01$ & $3.07405 \mathrm{E}-01$ & $-1.75707 \mathrm{E}+00$ \\
\hline 8.2 & $6.08361 \mathrm{E}-01$ & $-3.95150 \mathrm{E}-01$ & $3.03924 \mathrm{E}-01$ & $-1.71332 \mathrm{E}+00$ \\
\hline 8.4 & $6.10375 \mathrm{E}-01$ & $-4.14888 \mathrm{E}-01$ & $3.00208 \mathrm{E}-01$ & $-1.66803 \mathrm{E}+00$ \\
\hline 8.6 & $6.12409 \mathrm{E}-01$ & $-4.35473 \mathrm{E}-01$ & $2.96411 \mathrm{E}-01$ & $-1.62273 \mathrm{E}+00$ \\
\hline 8.8 & $6.14433 \mathrm{E}-01$ & $-4.56504 \mathrm{E}-01$ & $2.92690 \mathrm{E}-01$ & $-1.57892 \mathrm{E}+00$ \\
\hline
\end{tabular}

Continued 
Table A4. Concluded.

\begin{tabular}{|c|c|c|c|c|}
\hline$\alpha_{T}(\operatorname{deg})$ & $a_{0, \alpha_{T}}$ & $a_{1, \alpha_{T}}$ & $a_{2, \alpha_{T}}$ & $a_{12, \alpha_{T}}$ \\
\hline 9.0 & $6.16417 \mathrm{E}-01$ & $-4.77582 \mathrm{E}-01$ & $2.89201 \mathrm{E}-01$ & $-1.53810 \mathrm{E}+00$ \\
\hline 9.2 & $6.18333 \mathrm{E}-01$ & $-4.98321 \mathrm{E}-01$ & $2.86097 \mathrm{E}-01$ & $-1.50174 \mathrm{E}+00$ \\
\hline 9.4 & $6.20157 \mathrm{E}-01$ & $-5.18406 \mathrm{E}-01$ & $2.83513 \mathrm{E}-01$ & $-1.47111 \mathrm{E}+00$ \\
\hline 9.6 & $6.21869 \mathrm{E}-01$ & $-5.37540 \mathrm{E}-01$ & $2.81578 \mathrm{E}-01$ & $-1.44741 \mathrm{E}+00$ \\
\hline 9.8 & $6.23445 \mathrm{E}-01$ & $-5.55427 \mathrm{E}-01$ & $2.80423 \mathrm{E}-01$ & $-1.43186 \mathrm{E}+00$ \\
\hline 10.0 & $6.24865 \mathrm{E}-01$ & $-5.71771 \mathrm{E}-01$ & $2.80179 \mathrm{E}-01$ & $-1.42566 \mathrm{E}+00$ \\
\hline 10.2 & $6.26112 \mathrm{E}-01$ & $-5.86341 \mathrm{E}-01$ & $2.80950 \mathrm{E}-01$ & $-1.42979 \mathrm{E}+00$ \\
\hline 10.4 & $6.27196 \mathrm{E}-01$ & $-5.99212 \mathrm{E}-01$ & $2.82730 \mathrm{E}-01$ & $-1.44409 \mathrm{E}+00$ \\
\hline 10.6 & $6.28135 \mathrm{E}-01$ & $-6.10540 \mathrm{E}-01$ & $2.85472 \mathrm{E}-01$ & $-1.46807 \mathrm{E}+00$ \\
\hline 10.8 & $6.28946 \mathrm{E}-01$ & $-6.20485 \mathrm{E}-01$ & $2.89133 \mathrm{E}-01$ & $-1.50122 \mathrm{E}+00$ \\
\hline 11.0 & $6.29646 \mathrm{E}-01$ & $-6.29204 \mathrm{E}-01$ & $2.93666 \mathrm{E}-01$ & $-1.54304 \mathrm{E}+00$ \\
\hline 11.2 & $6.30252 \mathrm{E}-01$ & $-6.36863 \mathrm{E}-01$ & $2.99021 \mathrm{E}-01$ & $-1.59297 \mathrm{E}+00$ \\
\hline 11.4 & $6.30791 \mathrm{E}-01$ & $-6.43721 \mathrm{E}-01$ & $3.05086 \mathrm{E}-01$ & $-1.64992 \mathrm{E}+00$ \\
\hline 11.6 & $6.31295 \mathrm{E}-01$ & $-6.50093 \mathrm{E}-01$ & $3.11723 \mathrm{E}-01$ & $-1.71253 \mathrm{E}+00$ \\
\hline 11.8 & $6.31795 \mathrm{E}-01$ & $-6.56288 \mathrm{E}-01$ & $3.18791 \mathrm{E}-01$ & $-1.77943 \mathrm{E}+00$ \\
\hline 12.0 & $6.32323 \mathrm{E}-01$ & $-6.62621 \mathrm{E}-01$ & $3.26150 \mathrm{E}-01$ & $-1.84927 \mathrm{E}+00$ \\
\hline 12.2 & 6.32912E-01 & $-6.69409 \mathrm{E}-01$ & $3.33651 \mathrm{E}-01$ & $-1.92061 \mathrm{E}+00$ \\
\hline 12.4 & $6.33593 \mathrm{E}-01$ & $-6.76954 \mathrm{E}-01$ & $3.41119 \mathrm{E}-01$ & $-1.99182 \mathrm{E}+00$ \\
\hline 12.6 & $6.34397 \mathrm{E}-01$ & $-6.85546 \mathrm{E}-01$ & $3.48371 \mathrm{E}-01$ & $-2.06120 \mathrm{E}+00$ \\
\hline 12.8 & $6.35355 \mathrm{E}-01$ & $-6.95474 \mathrm{E}-01$ & $3.55223 \mathrm{E}-01$ & $-2.12708 \mathrm{E}+00$ \\
\hline 13.0 & $6.36497 \mathrm{E}-01$ & $-7.07029 \mathrm{E}-01$ & $3.61495 \mathrm{E}-01$ & $-2.18776 \mathrm{E}+00$ \\
\hline 13.2 & $6.37853 \mathrm{E}-01$ & $-7.20478 \mathrm{E}-01$ & $3.67009 \mathrm{E}-01$ & $-2.24163 \mathrm{E}+00$ \\
\hline 13.4 & $6.39441 \mathrm{E}-01$ & $-7.35980 \mathrm{E}-01$ & $3.71615 \mathrm{E}-01$ & $-2.28736 \mathrm{E}+00$ \\
\hline 13.6 & $6.41275 \mathrm{E}-01$ & $-7.53652 \mathrm{E}-01$ & $3.75178 \mathrm{E}-01$ & $-2.32373 \mathrm{E}+00$ \\
\hline 13.8 & $6.43371 \mathrm{E}-01$ & $-7.73614 \mathrm{E}-01$ & $3.77558 \mathrm{E}-01$ & $-2.34953 \mathrm{E}+00$ \\
\hline 14.0 & $6.45743 \mathrm{E}-01$ & $-7.95984 \mathrm{E}-01$ & $3.78618 \mathrm{E}-01$ & $-2.36354 \mathrm{E}+00$ \\
\hline 14.2 & $6.48403 \mathrm{E}-01$ & $-8.20863 \mathrm{E}-01$ & $3.78231 \mathrm{E}-01$ & $-2.36464 \mathrm{E}+00$ \\
\hline 14.4 & $6.51354 \mathrm{E}-01$ & $-8.48236 \mathrm{E}-01$ & $3.76337 \mathrm{E}-01$ & $-2.35234 \mathrm{E}+00$ \\
\hline 14.6 & $6.54588 \mathrm{E}-01$ & $-8.78040 \mathrm{E}-01$ & $3.72905 \mathrm{E}-01$ & $-2.32640 \mathrm{E}+00$ \\
\hline 14.8 & $6.58102 \mathrm{E}-01$ & $-9.10210 \mathrm{E}-01$ & $3.67902 \mathrm{E}-01$ & $-2.28655 \mathrm{E}+00$ \\
\hline 15.0 & 6.61891E-01 & $-9.44683 \mathrm{E}-01$ & $3.61297 \mathrm{E}-01$ & $-2.23256 \mathrm{E}+00$ \\
\hline 15.2 & $6.65948 \mathrm{E}-01$ & $-9.81378 \mathrm{E}-01$ & $3.53077 \mathrm{E}-01$ & $-2.16435 \mathrm{E}+00$ \\
\hline 15.4 & $6.70249 \mathrm{E}-01$ & $-1.02010 \mathrm{E}+00$ & $3.43357 \mathrm{E}-01$ & $-2.08293 \mathrm{E}+00$ \\
\hline 15.6 & $6.74767 \mathrm{E}-01$ & $-1.06061 \mathrm{E}+00$ & $3.32298 \mathrm{E}-01$ & $-1.98974 \mathrm{E}+00$ \\
\hline 15.8 & $6.79471 \mathrm{E}-01$ & $-1.10265 E+00$ & $3.20064 \mathrm{E}-01$ & $-1.88625 \mathrm{E}+00$ \\
\hline 16.0 & $6.84334 \mathrm{E}-01$ & $-1.14598 \mathrm{E}+00$ & $3.06820 \mathrm{E}-01$ & $-1.77388 \mathrm{E}+00$ \\
\hline 16.2 & $6.89328 \mathrm{E}-01$ & $-1.19036 \mathrm{E}+00$ & $2.92729 \mathrm{E}-01$ & $-1.65411 \mathrm{E}+00$ \\
\hline 16.4 & $6.94425 \mathrm{E}-01$ & $-1.23558 \mathrm{E}+00$ & $2.77953 \mathrm{E}-01$ & $-1.52834 \mathrm{E}+00$ \\
\hline 16.6 & 6.99602E-01 & $-1.28145 \mathrm{E}+00$ & $2.62658 \mathrm{E}-01$ & $-1.39804 \mathrm{E}+00$ \\
\hline 16.8 & 7.04833E-01 & $-1.32775 \mathrm{E}+00$ & $2.47009 \mathrm{E}-01$ & $-1.26462 \mathrm{E}+00$ \\
\hline 17.0 & 7.10094E-01 & $-1.37429 \mathrm{E}+00$ & $2.31168 \mathrm{E}-01$ & $-1.12953 \mathrm{E}+00$ \\
\hline
\end{tabular}


Table A5. Model for $C_{N}$ - DGB parachute.

\begin{tabular}{|c|c|c|c|c|}
\hline$\alpha_{T}(\mathrm{deg})$ & $a_{0, \alpha_{T}}$ & $a_{1, \alpha_{T}}$ & $a_{2, \alpha_{T}}$ & $a_{12, \alpha_{T}}$ \\
\hline 0.0 & $0.00000 \mathrm{E}+00$ & $0.00000 \mathrm{E}+00$ & $0.00000 \mathrm{E}+00$ & $0.00000 \mathrm{E}+0 \mathrm{C}$ \\
\hline 0.2 & $-3.21254 \mathrm{E}-03$ & $2.40254 \mathrm{E}-02$ & $-4.45051 \mathrm{E}-03$ & $3.66812 \mathrm{E}-02$ \\
\hline 0.4 & $-6.36652 \mathrm{E}-03$ & 4.75859E-02 & $-8.94423 \mathrm{E}-03$ & $7.38380 \mathrm{E}-02$ \\
\hline 0.6 & $-9.40375 \mathrm{E}-03$ & $7.02197 \mathrm{E}-02$ & $-1.35239 \mathrm{E}-02$ & $1.11941 \mathrm{E}-01$ \\
\hline 0.8 & $-1.22660 \mathrm{E}-02$ & $9.14650 \mathrm{E}-02$ & $-1.82321 \mathrm{E}-02$ & $1.51462 \mathrm{E}-01$ \\
\hline 1.0 & $-1.48951 \mathrm{E}-02$ & $1.10860 \mathrm{E}-01$ & $-2.31117 \mathrm{E}-02$ & $1.92870 \mathrm{E}-01$ \\
\hline 1.2 & $-1.72391 \mathrm{E}-02$ & $1.28002 \mathrm{E}-01$ & $-2.81926 \mathrm{E}-02$ & $2.36510 \mathrm{E}-01$ \\
\hline 1.4 & $-1.92747 \mathrm{E}-02$ & $1.42745 \mathrm{E}-01$ & $-3.34553 \mathrm{E}-02$ & $2.82242 \mathrm{E}-01$ \\
\hline 1.6 & $-2.09874 \mathrm{E}-02$ & $1.55023 \mathrm{E}-01$ & $-3.88688 \mathrm{E}-02$ & $3.29824 \mathrm{E}-01$ \\
\hline 1.8 & $-2.23629 \mathrm{E}-02$ & $1.64767 \mathrm{E}-01$ & $-4.44030 \mathrm{E}-02$ & $3.79018 \mathrm{E}-01$ \\
\hline 2.0 & $-2.33867 \mathrm{E}-02$ & $1.71910 \mathrm{E}-01$ & $-5.00275 \mathrm{E}-02$ & 4.29587E-01 \\
\hline 2.2 & $-2.40527 \mathrm{E}-02$ & $1.76459 \mathrm{E}-01$ & $-5.57009 \mathrm{E}-02$ & $4.81178 \mathrm{E}-01$ \\
\hline 2.4 & $-2.43879 \mathrm{E}-02$ & $1.78707 \mathrm{E}-01$ & $-6.13372 \mathrm{E}-02$ & $5.32993 \mathrm{E}-01$ \\
\hline 2.6 & $-2.44281 \mathrm{E}-02$ & $1.79024 \mathrm{E}-01$ & $-6.68375 \mathrm{E}-02$ & 5.84112E-01 \\
\hline 2.8 & $-2.42093 \mathrm{E}-02$ & $1.77781 \mathrm{E}-01$ & $-7.21030 \mathrm{E}-02$ & $6.33613 \mathrm{E}-01$ \\
\hline 3.0 & $-2.37673 \mathrm{E}-02$ & $1.75350 \mathrm{E}-01$ & $-7.70348 \mathrm{E}-02$ & $6.80576 \mathrm{E}-01$ \\
\hline 3.2 & $-2.31419 \mathrm{E}-02$ & $1.72128 \mathrm{E}-01$ & $-8.15358 \mathrm{E}-02$ & $7.24090 \mathrm{E}-01$ \\
\hline 3.4 & $-2.23834 \mathrm{E}-02$ & $1.68584 \mathrm{E}-01$ & $-8.55221 \mathrm{E}-02$ & $7.63346 \mathrm{E}-01$ \\
\hline 3.6 & $-2.15442 \mathrm{E}-02$ & $1.65194 \mathrm{E}-01$ & $-8.89131 \mathrm{E}-02$ & 7.97554E-01 \\
\hline 3.8 & $-2.06769 \mathrm{E}-02$ & $1.62437 \mathrm{E}-01$ & $-9.16283 \mathrm{E}-02$ & $8.25928 \mathrm{E}-01$ \\
\hline 4.0 & $-1.98338 \mathrm{E}-02$ & $1.60791 \mathrm{E}-01$ & $-9.35872 \mathrm{E}-02$ & $8.47679 \mathrm{E}-01$ \\
\hline 4.2 & $-1.90651 \mathrm{E}-02$ & $1.60702 \mathrm{E}-01$ & $-9.47225 \mathrm{E}-02$ & $8.62148 \mathrm{E}-01$ \\
\hline 4.4 & $-1.84036 \mathrm{E}-02$ & $1.62425 \mathrm{E}-01$ & $-9.50356 \mathrm{E}-02$ & $8.69304 \mathrm{E}-01$ \\
\hline 4.6 & $-1.78767 \mathrm{E}-02$ & $1.66154 \mathrm{E}-01$ & $-9.45479 \mathrm{E}-02$ & 8.69297E-01 \\
\hline 4.8 & $-1.75117 \mathrm{E}-02$ & $1.72082 \mathrm{E}-01$ & $-9.32810 \mathrm{E}-02$ & $8.62280 \mathrm{E}-01$ \\
\hline 5.0 & $-1.73357 \mathrm{E}-02$ & $1.80404 \mathrm{E}-01$ & $-9.12563 \mathrm{E}-02$ & $8.48404 \mathrm{E}-01$ \\
\hline 5.2 & $-1.73673 \mathrm{E}-02$ & $1.91221 \mathrm{E}-01$ & $-8.85179 \mathrm{E}-02$ & $8.28033 \mathrm{E}-01$ \\
\hline 5.4 & $-1.75805 \mathrm{E}-02$ & $2.04187 \mathrm{E}-01$ & $-8.52207 \mathrm{E}-02$ & $8.02590 \mathrm{E}-01$ \\
\hline 5.6 & $-1.79344 \mathrm{E}-02$ & $2.18803 \mathrm{E}-01$ & $-8.15597 \mathrm{E}-02$ & 7.73877E-01 \\
\hline 5.8 & $-1.83879 \mathrm{E}-02$ & $2.34567 \mathrm{E}-01$ & $-7.77303 \mathrm{E}-02$ & $7.43696 \mathrm{E}-01$ \\
\hline 6.0 & $-1.89000 \mathrm{E}-02$ & $2.50979 \mathrm{E}-01$ & $-7.39274 \mathrm{E}-02$ & $7.13853 \mathrm{E}-01$ \\
\hline 6.2 & $-1.94291 \mathrm{E}-02$ & $2.67539 \mathrm{E}-01$ & $-7.03422 \mathrm{E}-02$ & $6.86114 \mathrm{E}-01$ \\
\hline 6.4 & $-1.99328 \mathrm{E}-02$ & $2.83740 \mathrm{E}-01$ & $-6.71441 \mathrm{E}-02$ & $6.62067 \mathrm{E}-01$ \\
\hline 6.6 & $-2.03685 \mathrm{E}-02$ & $2.99079 \mathrm{E}-01$ & $-6.44958 \mathrm{E}-02$ & $6.43247 \mathrm{E}-01$ \\
\hline 6.8 & $-2.06937 \mathrm{E}-02$ & $3.13051 \mathrm{E}-01$ & $-6.25600 \mathrm{E}-02$ & $6.31185 \mathrm{E}-01$ \\
\hline 7.0 & $-2.08660 \mathrm{E}-02$ & $3.25152 \mathrm{E}-01$ & $-6.14993 \mathrm{E}-02$ & 6.27413E-01 \\
\hline 7.2 & $-2.08461 \mathrm{E}-02$ & $3.34918 \mathrm{E}-01$ & $-6.14628 \mathrm{E}-02$ & $6.33339 \mathrm{E}-01$ \\
\hline 7.4 & $-2.06197 \mathrm{E}-02$ & $3.42145 \mathrm{E}-01$ & $-6.25021 \mathrm{E}-02$ & $6.49468 \mathrm{E}-01$ \\
\hline 7.6 & $-2.01830 \mathrm{E}-02$ & $3.46738 \mathrm{E}-01$ & $-6.46259 \mathrm{E}-02$ & $6.75920 \mathrm{E}-01$ \\
\hline 7.8 & $-1.95325 \mathrm{E}-02$ & $3.48602 \mathrm{E}-01$ & $-6.78430 \mathrm{E}-02$ & 7.12812E-01 \\
\hline 8.0 & $-1.86645 \mathrm{E}-02$ & $3.47644 \mathrm{E}-01$ & $-7.21618 \mathrm{E}-02$ & $7.60261 \mathrm{E}-01$ \\
\hline 8.2 & $-1.75806 \mathrm{E}-02$ & $3.43825 \mathrm{E}-01$ & $-7.75739 \mathrm{E}-02$ & $8.18225 \mathrm{E}-01$ \\
\hline 8.4 & $-1.63114 \mathrm{E}-02$ & $3.37422 \mathrm{E}-01$ & $-8.39684 \mathrm{E}-02$ & $8.85696 \mathrm{E}-01$ \\
\hline 8.6 & $-1.48997 \mathrm{E}-02$ & $3.28835 \mathrm{E}-01$ & $-9.11895 \mathrm{E}-02$ & $9.61247 \mathrm{E}-01$ \\
\hline 8.8 & $-1.33885 \mathrm{E}-02$ & $3.18466 \mathrm{E}-01$ & $-9.90811 \mathrm{E}-02$ & $1.04345 \mathrm{E}+00$ \\
\hline
\end{tabular}

Continued 
Table A5. Concluded.

\begin{tabular}{|c|c|c|c|c|}
\hline$\alpha_{T}(\mathrm{deg})$ & $a_{0, \alpha_{T}}$ & $a_{1, \alpha_{T}}$ & $a_{2, \alpha_{T}}$ & $a_{12, \alpha_{T}}$ \\
\hline 9.0 & $-1.18208 \mathrm{E}-02$ & $3.06716 \mathrm{E}-01$ & $-1.07487 \mathrm{E}-01$ & $1.13088 \mathrm{E}+00$ \\
\hline 9.2 & $-1.02412 \mathrm{E}-02$ & $2.94010 \mathrm{E}-01$ & $-1.16246 \mathrm{E}-01$ & $1.22206 \mathrm{E}+00$ \\
\hline 9.4 & $-8.70518 \mathrm{E}-03$ & $2.80902 \mathrm{E}-01$ & $-1.25160 \mathrm{E}-01$ & $1.31513 \mathrm{E}+0 \mathrm{C}$ \\
\hline 9.6 & $-7.27204 \mathrm{E}-03$ & $2.67998 \mathrm{E}-01$ & $-1.34012 \mathrm{E}-01$ & $1.40807 \mathrm{E}+0 \mathrm{C}$ \\
\hline 9.8 & $-6.00116 \mathrm{E}-03$ & $2.55900 \mathrm{E}-01$ & $-1.42587 \mathrm{E}-01$ & $1.49888 \mathrm{E}+0 \mathrm{C}$ \\
\hline 10.0 & $-4.95189 \mathrm{E}-03$ & $2.45211 \mathrm{E}-01$ & $-1.50671 \mathrm{E}-01$ & $1.58554 \mathrm{E}+0 \mathrm{C}$ \\
\hline 10.2 & $-4.17627 \mathrm{E}-03$ & $2.36475 \mathrm{E}-01$ & $-1.58068 \mathrm{E}-01$ & $1.66621 \mathrm{E}+00$ \\
\hline 10.4 & $-3.69988 \mathrm{E}-03$ & $2.30011 \mathrm{E}-01$ & $-1.64671 \mathrm{E}-01$ & $1.73984 \mathrm{E}+00$ \\
\hline 10.6 & $-3.53934 \mathrm{E}-03$ & $2.26060 \mathrm{E}-01$ & $-1.70399 \mathrm{E}-01$ & $1.80559 \mathrm{E}+0 \mathrm{C}$ \\
\hline 10.8 & $-3.71109 \mathrm{E}-03$ & $2.24861 \mathrm{E}-01$ & $-1.75171 \mathrm{E}-01$ & $1.86266 \mathrm{E}+0 \mathrm{C}$ \\
\hline 11.0 & $-4.23158 \mathrm{E}-03$ & $2.26655 \mathrm{E}-01$ & $-1.78907 \mathrm{E}-01$ & $1.91024 \mathrm{E}+0 \mathrm{C}$ \\
\hline 11.2 & $-5.11372 \mathrm{E}-03$ & $2.31647 \mathrm{E}-01$ & $-1.81538 \mathrm{E}-01$ & $1.94762 \mathrm{E}+00$ \\
\hline 11.4 & $-6.34811 \mathrm{E}-03$ & $2.39823 \mathrm{E}-01$ & $-1.83071 \mathrm{E}-01$ & $1.97480 \mathrm{E}+00$ \\
\hline 11.6 & $-7.91623 \mathrm{E}-03$ & $2.51085 \mathrm{E}-01$ & $-1.83542 \mathrm{E}-01$ & $1.99207 \mathrm{E}+00$ \\
\hline 11.8 & $-9.79951 \mathrm{E}-03$ & $2.65331 \mathrm{E}-01$ & $-1.82991 \mathrm{E}-01$ & $1.99973 \mathrm{E}+0 \mathrm{C}$ \\
\hline 12.0 & $-1.19794 \mathrm{E}-02$ & $2.82464 \mathrm{E}-01$ & $-1.81455 \mathrm{E}-01$ & $1.99809 \mathrm{E}+0 \mathrm{C}$ \\
\hline 12.2 & $-1.44342 \mathrm{E}-02$ & $3.02347 \mathrm{E}-01$ & $-1.78984 \mathrm{E}-01$ & $1.98756 \mathrm{E}+0 \mathrm{C}$ \\
\hline 12.4 & $-1.71284 \mathrm{E}-02$ & $3.24698 \mathrm{E}-01$ & $-1.75682 \mathrm{E}-01$ & $1.96908 \mathrm{E}+00$ \\
\hline 12.6 & $-2.00228 \mathrm{E}-02$ & $3.49190 \mathrm{E}-01$ & $-1.71663 \mathrm{E}-01$ & $1.94370 \mathrm{E}+00$ \\
\hline 12.8 & $-2.30778 \mathrm{E}-02$ & $3.75495 \mathrm{E}-01$ & $-1.67045 \mathrm{E}-01$ & $1.91252 \mathrm{E}+00$ \\
\hline 13.0 & $-2.62542 \mathrm{E}-02$ & $4.03286 \mathrm{E}-01$ & $-1.61944 \mathrm{E}-01$ & $1.87659 \mathrm{E}+0 \mathrm{c}$ \\
\hline 13.2 & $-2.95149 \mathrm{E}-02$ & $4.32255 \mathrm{E}-01$ & $-1.56472 \mathrm{E}-01$ & $1.83695 \mathrm{E}+0 \mathrm{C}$ \\
\hline 13.4 & $-3.28285 \mathrm{E}-02$ & $4.62127 \mathrm{E}-01$ & $-1.50733 \mathrm{E}-01$ & $1.79459 \mathrm{E}+00$ \\
\hline 13.6 & $-3.61637 \mathrm{E}-02$ & $4.92624 \mathrm{E}-01$ & $-1.44834 \mathrm{E}-01$ & $1.75050 \mathrm{E}+0 \mathrm{C}$ \\
\hline 13.8 & $-3.94893 \mathrm{E}-02$ & $5.23466 \mathrm{E}-01$ & $-1.38883 \mathrm{E}-01$ & $1.70570 \mathrm{E}+0 \mathrm{C}$ \\
\hline 14.0 & $-4.27740 \mathrm{E}-02$ & $5.54373 \mathrm{E}-01$ & $-1.32985 \mathrm{E}-01$ & $1.66121 \mathrm{E}+00$ \\
\hline 14.2 & $-4.59888 \mathrm{E}-02$ & $5.85084 \mathrm{E}-01$ & $-1.27241 \mathrm{E}-01$ & $1.61796 \mathrm{E}+0 \mathrm{C}$ \\
\hline 14.4 & $-4.91157 \mathrm{E}-02$ & $6.15420 \mathrm{E}-01$ & $-1.21719 \mathrm{E}-01$ & $1.57661 \mathrm{E}+00$ \\
\hline 14.6 & $-5.21403 \mathrm{E}-02$ & $6.45229 \mathrm{E}-01$ & $-1.16474 \mathrm{E}-01$ & $1.53773 \mathrm{E}+00$ \\
\hline 14.8 & $-5.50482 \mathrm{E}-02$ & $6.74361 \mathrm{E}-01$ & $-1.11564 \mathrm{E}-01$ & $1.50187 \mathrm{E}+0 \mathrm{C}$ \\
\hline 15.0 & $-5.78252 \mathrm{E}-02$ & $7.02666 \mathrm{E}-01$ & $-1.07044 \mathrm{E}-01$ & $1.46958 \mathrm{E}+0 \mathrm{C}$ \\
\hline 15.2 & $-6.04596 \mathrm{E}-02$ & $7.30016 \mathrm{E}-01$ & $-1.02961 \mathrm{E}-01$ & $1.44133 \mathrm{E}+0 \mathrm{C}$ \\
\hline 15.4 & $-6.29568 \mathrm{E}-02$ & $7.56427 \mathrm{E}-01$ & $-9.93002 \mathrm{E}-02$ & $1.41698 \mathrm{E}+00$ \\
\hline 15.6 & $-6.53309 \mathrm{E}-02$ & $7.81986 \mathrm{E}-01$ & $-9.60201 \mathrm{E}-02$ & $1.39616 \mathrm{E}+00$ \\
\hline 15.8 & $-6.75958 \mathrm{E}-02$ & $8.06783 \mathrm{E}-01$ & $-9.30800 \mathrm{E}-02$ & $1.37851 \mathrm{E}+0 \mathrm{C}$ \\
\hline 16.0 & $-6.97656 \mathrm{E}-02$ & $8.30907 \mathrm{E}-01$ & $-9.04386 \mathrm{E}-02$ & $1.36365 \mathrm{E}+00$ \\
\hline 16.2 & $-7.18546 \mathrm{E}-02$ & $8.54450 \mathrm{E}-01$ & $-8.80540 \mathrm{E}-02$ & $1.35119 \mathrm{E}+0 \mathrm{c}$ \\
\hline 16.4 & $-7.38776 \mathrm{E}-02$ & $8.77516 \mathrm{E}-01$ & $-8.58784 \mathrm{E}-02$ & $1.34069 \mathrm{E}+0 \mathrm{C}$ \\
\hline 16.6 & $-7.58502 \mathrm{E}-02$ & $9.00217 \mathrm{E}-01$ & $-8.38618 \mathrm{E}-02$ & $1.33169 \mathrm{E}+00$ \\
\hline 16.8 & $-7.77880 \mathrm{E}-02$ & $9.22662 \mathrm{E}-01$ & $-8.19542 \mathrm{E}-02$ & $1.32370 \mathrm{E}+0 \mathrm{C}$ \\
\hline 17.0 & $-7.97062 \mathrm{E}-02$ & $9.44963 \mathrm{E}-01$ & $-8.01056 \mathrm{E}-02$ & $1.31627 \mathrm{E}+0 \mathrm{C}$ \\
\hline
\end{tabular}


Table A6. Model for $C_{m, \mathrm{SLCP}}$ - DGB parachute.

\begin{tabular}{|c|c|c|c|c|}
\hline$\alpha_{T}(\operatorname{deg})$ & $a_{0, \alpha_{T}}$ & $a_{1, \alpha_{T}}$ & $a_{2, \alpha_{T}}$ & $a_{12, \alpha_{T}}$ \\
\hline 0.0 & $0.00000 \mathrm{E}+00$ & $0.00000 \mathrm{E}+00$ & $0.00000 \mathrm{E}+00$ & $0.00000 \mathrm{E}+00$ \\
\hline 0.2 & $5.56435 \mathrm{E}-03$ & $-4.20859 \mathrm{E}-02$ & 7.68344E-03 & $-6.66235 \mathrm{E}-02$ \\
\hline 0.4 & $1.10322 \mathrm{E}-02$ & $-8.34040 \mathrm{E}-02$ & $1.54353 \mathrm{E}-02$ & $-1.33964 \mathrm{E}-01$ \\
\hline 0.6 & $1.63076 \mathrm{E}-02$ & $-1.23192 \mathrm{E}-01$ & 2.33229E-02 & $-2.02728 \mathrm{E}-01$ \\
\hline 0.8 & $2.12946 \mathrm{E}-02$ & $-1.60689 \mathrm{E}-01$ & $3.14137 \mathrm{E}-02$ & $-2.73622 \mathrm{E}-01$ \\
\hline 1.0 & $2.58974 \mathrm{E}-02$ & $-1.95132 \mathrm{E}-01$ & 3.97749E-02 & $-3.47353 \mathrm{E}-01$ \\
\hline 1.2 & $3.00304 \mathrm{E}-02$ & $-2.25854 \mathrm{E}-01$ & 4.84542E-02 & $-4.24431 \mathrm{E}-01$ \\
\hline 1.4 & $3.36543 \mathrm{E}-02$ & $-2.52607 \mathrm{E}-01$ & $5.74181 \mathrm{E}-02$ & $-5.04596 \mathrm{E}-01$ \\
\hline 1.6 & $3.67451 \mathrm{E}-02$ & $-2.75273 \mathrm{E}-01$ & 6.66139E-02 & $-5.87410 \mathrm{E}-01$ \\
\hline 1.8 & $3.92790 \mathrm{E}-02$ & $-2.93737 \mathrm{E}-01$ & 7.59891E-02 & $-6.72439 \mathrm{E}-01$ \\
\hline 2.0 & $4.12318 \mathrm{E}-02$ & $-3.07881 \mathrm{E}-01$ & $8.54916 \mathrm{E}-02$ & $-7.59250 \mathrm{E}-01$ \\
\hline 2.2 & 4.25932E-02 & $-3.17707 \mathrm{E}-01$ & $9.50510 \mathrm{E}-02$ & $-8.47230 \mathrm{E}-01$ \\
\hline 2.4 & 4.34069E-02 & $-3.23688 \mathrm{E}-01$ & $1.04525 \mathrm{E}-01$ & $-9.35066 \mathrm{E}-01$ \\
\hline 2.6 & 4.37313E-02 & $-3.26421 \mathrm{E}-01$ & $1.13750 \mathrm{E}-01$ & $-1.02125 \mathrm{E}+00$ \\
\hline 2.8 & 4.36249E-02 & $-3.26505 \mathrm{E}-01$ & $1.22564 \mathrm{E}-01$ & $-1.10427 \mathrm{E}+00$ \\
\hline 3.0 & $4.31461 \mathrm{E}-02$ & $-3.24538 \mathrm{E}-01$ & $1.30803 \mathrm{E}-01$ & $-1.18262 \mathrm{E}+00$ \\
\hline 3.2 & $4.23595 \mathrm{E}-02$ & $-3.21164 \mathrm{E}-01$ & $1.38308 \mathrm{E}-01$ & $-1.25483 \mathrm{E}+00$ \\
\hline 3.4 & $4.13469 \mathrm{E}-02$ & $-3.17134 \mathrm{E}-01$ & $1.44941 \mathrm{E}-01$ & $-1.31958 \mathrm{E}+00$ \\
\hline 3.6 & 4.01935E-02 & $-3.13220 \mathrm{E}-01$ & $1.50574 \mathrm{E}-01$ & $-1.37566 \mathrm{E}+00$ \\
\hline 3.8 & $3.89847 \mathrm{E}-02$ & $-3.10191 \mathrm{E}-01$ & $1.55076 \mathrm{E}-01$ & $-1.42181 \mathrm{E}+00$ \\
\hline 4.0 & $3.78058 \mathrm{E}-02$ & $-3.08819 \mathrm{E}-01$ & $1.58318 \mathrm{E}-01$ & $-1.45679 \mathrm{E}+00$ \\
\hline 4.2 & $3.67380 \mathrm{E}-02$ & $-3.09821 \mathrm{E}-01$ & $1.60190 \mathrm{E}-01$ & $-1.47958 \mathrm{E}+00$ \\
\hline 4.4 & $3.58344 \mathrm{E}-02$ & $-3.13603 \mathrm{E}-01$ & $1.60700 \mathrm{E}-01$ & $-1.49020 \mathrm{E}+00$ \\
\hline 4.6 & $3.51389 \mathrm{E}-02$ & $-3.20472 \mathrm{E}-01$ & $1.59888 \mathrm{E}-01$ & $-1.48897 \mathrm{E}+00$ \\
\hline 4.8 & $3.46954 \mathrm{E}-02$ & $-3.30734 \mathrm{E}-01$ & $1.57793 \mathrm{E}-01$ & $-1.47620 \mathrm{E}+00$ \\
\hline 5.0 & $3.45478 \mathrm{E}-02$ & $-3.44694 \mathrm{E}-01$ & $1.54455 \mathrm{E}-01$ & $-1.45224 \mathrm{E}+00$ \\
\hline 5.2 & $3.47256 \mathrm{E}-02$ & $-3.62513 \mathrm{E}-01$ & $1.49950 \mathrm{E}-01$ & $-1.41773 \mathrm{E}+00$ \\
\hline 5.4 & $3.51867 \mathrm{E}-02$ & $-3.83629 \mathrm{E}-01$ & $1.44536 \mathrm{E}-01$ & $-1.37505 \mathrm{E}+00$ \\
\hline 5.6 & $3.58641 \mathrm{E}-02$ & $-4.07235 \mathrm{E}-01$ & $1.38537 \mathrm{E}-01$ & $-1.32719 \mathrm{E}+00$ \\
\hline 5.8 & $3.66911 \mathrm{E}-02$ & $-4.32519 \mathrm{E}-01$ & $1.32275 \mathrm{E}-01$ & $-1.27715 \mathrm{E}+00$ \\
\hline 6.0 & $3.76005 \mathrm{E}-02$ & $-4.58674 \mathrm{E}-01$ & $1.26075 \mathrm{E}-01$ & $-1.22792 \mathrm{E}+00$ \\
\hline 6.2 & $3.85250 \mathrm{E}-02$ & $-4.84888 \mathrm{E}-01$ & $1.20252 \mathrm{E}-01$ & $-1.18242 \mathrm{E}+00$ \\
\hline 6.4 & $3.93962 \mathrm{E}-02$ & $-5.10358 \mathrm{E}-01$ & $1.15085 \mathrm{E}-01$ & $-1.14325 \mathrm{E}+00$ \\
\hline 6.6 & 4.01460E-02 & $-5.34284 \mathrm{E}-01$ & $1.10841 \mathrm{E}-01$ & $-1.11292 \mathrm{E}+00$ \\
\hline 6.8 & 4.07063E-02 & $-5.55864 \mathrm{E}-01$ & $1.07785 \mathrm{E}-01$ & $-1.09391 \mathrm{E}+00$ \\
\hline 7.0 & $4.10088 \mathrm{E}-02$ & $-5.74300 \mathrm{E}-01$ & $1.06185 \mathrm{E}-01$ & $-1.08873 \mathrm{E}+00$ \\
\hline 7.2 & 4.09913E-02 & $-5.88856 \mathrm{E}-01$ & $1.06283 \mathrm{E}-01$ & $-1.09967 \mathrm{E}+00$ \\
\hline 7.4 & $4.06318 \mathrm{E}-02$ & $-5.99229 \mathrm{E}-01$ & $1.08162 \mathrm{E}-01$ & $-1.12750 \mathrm{E}+00$ \\
\hline 7.6 & $3.99267 \mathrm{E}-02$ & $-6.05293 \mathrm{E}-01$ & $1.11831 \mathrm{E}-01$ & $-1.17237 \mathrm{E}+00$ \\
\hline 7.8 & $3.88721 \mathrm{E}-02$ & $-6.06926 \mathrm{E}-01$ & $1.17301 \mathrm{E}-01$ & $-1.23443 \mathrm{E}+00$ \\
\hline 8.0 & $3.74644 \mathrm{E}-02$ & $-6.04004 \mathrm{E}-01$ & $1.24582 \mathrm{E}-01$ & $-1.31380 \mathrm{E}+00$ \\
\hline 8.2 & $3.57079 \mathrm{E}-02$ & $-5.96495 \mathrm{E}-01$ & $1.33656 \mathrm{E}-01$ & $-1.41038 \mathrm{E}+00$ \\
\hline 8.4 & $3.36542 \mathrm{E}-02$ & $-5.84867 \mathrm{E}-01$ & $1.44337 \mathrm{E}-01$ & $-1.52246 \mathrm{E}+00$ \\
\hline 8.6 & $3.13746 \mathrm{E}-02$ & $-5.69793 \mathrm{E}-01$ & $1.56367 \mathrm{E}-01$ & $-1.64768 \mathrm{E}+00$ \\
\hline 8.8 & $2.89407 \mathrm{E}-02$ & $-5.51947 \mathrm{E}-01$ & $1.69486 \mathrm{E}-01$ & $-1.78364 \mathrm{E}+00$ \\
\hline
\end{tabular}

Continued 
Table A6. Concluded.

\begin{tabular}{|c|c|c|c|c|}
\hline$\alpha_{T}(\operatorname{deg})$ & $a_{0, \alpha_{T}}$ & $a_{1, \alpha_{T}}$ & $a_{2, \alpha_{T}}$ & $a_{12, \alpha_{T}}$ \\
\hline 9.0 & $2.64241 \mathrm{E}-02$ & $-5.32004 \mathrm{E}-01$ & $1.83434 \mathrm{E}-01$ & $-1.92797 \mathrm{E}+00$ \\
\hline 9.2 & $2.38991 \mathrm{E}-02$ & $-5.10672 \mathrm{E}-01$ & $1.97944 \mathrm{E}-01$ & $-2.07821 \mathrm{E}+00$ \\
\hline 9.4 & $2.14559 \mathrm{E}-02$ & $-4.88854 \mathrm{E}-01$ & $2.12688 \mathrm{E}-01$ & $-2.23132 \mathrm{E}+00$ \\
\hline 9.6 & $1.91910 \mathrm{E}-02$ & $-4.67529 \mathrm{E}-01$ & $2.27314 \mathrm{E}-01$ & $-2.38401 \mathrm{E}+00$ \\
\hline 9.8 & $1.72009 \mathrm{E}-02$ & $-4.47675 \mathrm{E}-01$ & $2.41470 \mathrm{E}-01$ & $-2.53299 \mathrm{E}+00$ \\
\hline 10.0 & $1.55820 \mathrm{E}-02$ & $-4.30270 \mathrm{E}-01$ & $2.54802 \mathrm{E}-01$ & $-2.67497 \mathrm{E}+00$ \\
\hline 10.2 & $1.44185 \mathrm{E}-02$ & $-4.16187 \mathrm{E}-01$ & $2.66995 \mathrm{E}-01$ & $-2.80697 \mathrm{E}+00$ \\
\hline 10.4 & $1.37494 \mathrm{E}-02$ & $-4.05915 \mathrm{E}-01$ & $2.77876 \mathrm{E}-01$ & $-2.92732 \mathrm{E}+00$ \\
\hline 10.6 & $1.35990 \mathrm{E}-02$ & $-3.99808 \mathrm{E}-01$ & $2.87320 \mathrm{E}-01$ & $-3.03474 \mathrm{E}+00$ \\
\hline 10.8 & $1.39914 \mathrm{E}-02$ & $-3.98220 \mathrm{E}-01$ & $2.95203 \mathrm{E}-01$ & $-3.12801 \mathrm{E}+00$ \\
\hline 11.0 & $1.49503 \mathrm{E}-02$ & $-4.01504 \mathrm{E}-01$ & $3.01400 \mathrm{E}-01$ & $-3.20586 \mathrm{E}+00$ \\
\hline 11.2 & $1.64944 \mathrm{E}-02$ & $-4.09960 \mathrm{E}-01$ & $3.05804 \mathrm{E}-01$ & $-3.26723 \mathrm{E}+00$ \\
\hline 11.4 & $1.86064 \mathrm{E}-02$ & $-4.23542 \mathrm{E}-01$ & $3.08432 \mathrm{E}-01$ & $-3.31216 \mathrm{E}+00$ \\
\hline 11.6 & $2.12546 \mathrm{E}-02$ & $-4.42067 \mathrm{E}-01$ & $3.09348 \mathrm{E}-01$ & $-3.34120 \mathrm{E}+00$ \\
\hline 11.8 & $2.44071 \mathrm{E}-02$ & $-4.65348 \mathrm{E}-01$ & $3.08621 \mathrm{E}-01$ & $-3.35488 \mathrm{E}+00$ \\
\hline 12.0 & $2.80320 \mathrm{E}-02$ & $-4.93200 \mathrm{E}-01$ & $3.06316 \mathrm{E}-01$ & $-3.35374 \mathrm{E}+00$ \\
\hline 12.2 & $3.20928 \mathrm{E}-02$ & $-5.25387 \mathrm{E}-01$ & $3.02520 \mathrm{E}-01$ & $-3.33851 \mathrm{E}+00$ \\
\hline 12.4 & 3.65324E-02 & $-5.61454 \mathrm{E}-01$ & $2.97400 \mathrm{E}-01$ & $-3.31069 \mathrm{E}+00$ \\
\hline 12.6 & $4.12881 \mathrm{E}-02$ & $-6.00881 \mathrm{E}-01$ & $2.91142 \mathrm{E}-01$ & $-3.27203 \mathrm{E}+00$ \\
\hline 12.8 & $4.62969 \mathrm{E}-02$ & $-6.43148 \mathrm{E}-01$ & $2.83937 \mathrm{E}-01$ & $-3.22423 \mathrm{E}+00$ \\
\hline 13.0 & $5.14962 \mathrm{E}-02$ & $-6.87736 \mathrm{E}-01$ & $2.75970 \mathrm{E}-01$ & $-3.16903 \mathrm{E}+00$ \\
\hline 13.2 & $5.68269 \mathrm{E}-02$ & $-7.34157 \mathrm{E}-01$ & $2.67424 \mathrm{E}-01$ & $-3.10808 \mathrm{E}+00$ \\
\hline 13.4 & $6.22401 \mathrm{E}-02$ & $-7.81990 \mathrm{E}-01$ & $2.58464 \mathrm{E}-01$ & $-3.04293 \mathrm{E}+00$ \\
\hline 13.6 & 6.76877E-02 & $-8.30811 \mathrm{E}-01$ & $2.49258 \mathrm{E}-01$ & $-2.97517 \mathrm{E}+00$ \\
\hline 13.8 & 7.31214E-02 & $-8.80196 \mathrm{E}-01$ & $2.39976 \mathrm{E}-01$ & $-2.90637 \mathrm{E}+00$ \\
\hline 14.0 & $7.84929 \mathrm{E}-02$ & $-9.29720 \mathrm{E}-01$ & $2.30785 \mathrm{E}-01$ & $-2.83812 \mathrm{E}+00$ \\
\hline 14.2 & $8.37577 \mathrm{E}-02$ & $-9.78987 \mathrm{E}-01$ & $2.21842 \mathrm{E}-01$ & $-2.77189 \mathrm{E}+00$ \\
\hline 14.4 & $8.88889 \mathrm{E}-02$ & $-1.02773 \mathrm{E}+00$ & $2.13253 \mathrm{E}-01$ & $-2.70869 \mathrm{E}+00$ \\
\hline 14.6 & $9.38654 \mathrm{E}-02$ & $-1.07575 \mathrm{E}+00$ & $2.05102 \mathrm{E}-01$ & $-2.64936 \mathrm{E}+00$ \\
\hline 14.8 & $9.86666 \mathrm{E}-02$ & $-1.12281 \mathrm{E}+00$ & $1.97476 \mathrm{E}-01$ & $-2.59473 \mathrm{E}+00$ \\
\hline 15.0 & $1.03272 \mathrm{E}-01$ & $-1.16870 \mathrm{E}+00$ & $1.90459 \mathrm{E}-01$ & $-2.54565 \mathrm{E}+00$ \\
\hline 15.2 & $1.07663 \mathrm{E}-01$ & $-1.21325 \mathrm{E}+00$ & $1.84123 \mathrm{E}-01$ & $-2.50281 \mathrm{E}+00$ \\
\hline 15.4 & $1.11850 \mathrm{E}-01$ & $-1.25646 \mathrm{E}+00$ & $1.78443 \mathrm{E}-01$ & $-2.46599 \mathrm{E}+00$ \\
\hline 15.6 & $1.15853 \mathrm{E}-01$ & $-1.29846 \mathrm{E}+00$ & $1.73356 \mathrm{E}-01$ & $-2.43462 \mathrm{E}+00$ \\
\hline 15.8 & $1.19694 \mathrm{E}-01$ & $-1.33940 \mathrm{E}+00$ & $1.68795 \mathrm{E}-01$ & $-2.40812 \mathrm{E}+00$ \\
\hline 16.0 & $1.23393 \mathrm{E}-01$ & $-1.37938 \mathrm{E}+00$ & $1.64696 \mathrm{E}-01$ & $-2.38589 \mathrm{E}+00$ \\
\hline 16.2 & $1.26973 \mathrm{E}-01$ & $-1.41855 \mathrm{E}+00$ & $1.60993 \mathrm{E}-01$ & $-2.36734 \mathrm{E}+00$ \\
\hline 16.4 & $1.30455 \mathrm{E}-01$ & $-1.45705 \mathrm{E}+00$ & $1.57613 \mathrm{E}-01$ & $-2.35179 \mathrm{E}+00$ \\
\hline 16.6 & $1.33863 \mathrm{E}-01$ & $-1.49504 \mathrm{E}+00$ & $1.54477 \mathrm{E}-01$ & $-2.33852 \mathrm{E}+00$ \\
\hline 16.8 & $1.37218 \mathrm{E}-01$ & $-1.53267 \mathrm{E}+00$ & $1.51510 \mathrm{E}-01$ & $-2.32682 \mathrm{E}+00$ \\
\hline 17.0 & $1.40545 \mathrm{E}-01$ & $-1.57009 \mathrm{E}+00$ & $1.48634 \mathrm{E}-01$ & $-2.31596 \mathrm{E}+00$ \\
\hline
\end{tabular}




\section{Acknowledgments}

The authors thank the following individuals for their assistance with the work presented herein. Carlie H. Zumwalt, Clara O'Farrell, and Donald F. Keller for making available the unpublished static coefficients source data. Justin S. Green of the NASA Langley Research Center for his assistance with MATLAB $^{\circledR}$ analyses and for providing comments regarding the models. Dr. Drew Landman of Old Dominion University for providing advice on the linear regression models and reviewing the manuscript.

\section{References}

${ }^{1}$ Cruz, J. R., Way, D. W., Shidner, J. D., Davis, J. L., Powell, R. W., Kipp, D. M., Adams, D. S., Sengupta, A., Witkowski, A., and Kandis, M., "Parachute Models Used in the Mars Science Laboratory Entry, Descent, and Landing Simulation, AIAA Paper 2013-1276, presented at the $22^{\text {nd }}$ AIAA Aerodynamic Decelerator Systems Technology Conference and Seminar, Daytona Beach, FL, March 25-28, 2013.

${ }^{2}$ Zumwalt, C. H., Cruz, J. R., Keller, D. F., and O'Farrell, C., "Wind Tunnel Test of Subscale Ringsail and Disk-Gap-Band Parachutes," AIAA Paper 2016-3426, presented at the $34^{\text {th }}$ AIAA Applied Aerodynamics Conference, Washington, DC, June 13-17, 2016.

${ }^{3}$ Cruz, J. R., O'Farrell, C., Hennings, E., and Runnells, P., "Permeability of Two Parachute Fabrics - Measurements, Modeling, and Application," NASA TM 2016-219328 (Corrected Copy), July 2016. (Also available as an AIAA paper presented at the $24^{\text {th }}$ AIAA Aerodynamic Decelerator Systems Technology Conference, Denver, CO, June 5-9, 2017.)

${ }^{4}$ Clark, I., Adler, M., Rivellini, T., "Development and Testing of a New Family of Supersonic Decelerators," AIAA Paper 2013-1252, presented at the $22^{\text {nd }}$ AIAA Aerodynamic Decelerator Systems Technology Conference and Seminar, March 25-28, 2013

${ }^{5}$ Parachute Industry Association, "Commercial Specification, Cloth, Parachute, Nylon-Rip Stop and Will Weave," PIA-C-7020D, November 17, 2010.

${ }^{6}$ Parachute Industry Association, “Commercial Specification, Cloth, Parachute, Nylon, Low Permeability,” PIA-C-44378D, May 3, 2007.

${ }^{7}$ Lingard, J. and Underwood, J, "The Effect of Low Density Atmospheres on the Aerodynamic Coefficients of Parachutes," AIAA Paper 95-1556, presented at the $13^{\text {th }}$ AIAA Aerodynamic Decelerator Systems Technology Conference, Clearwater, FL, May 15-19, 1995.

${ }^{8}$ Lingard, S., "Aerodynamics 1 (Steady)," lecture notes for the Parachute Systems Technology Short Course, U. S. Army Proving Ground, May 12-16, 2008.

${ }^{9}$ Cruz, J. R. and Snyder, M. L., "Estimates for the Aerodynamic Coefficients of Ringsail and Disk-Gap-Band Parachutes Operating on Mars," NASA Technical Memorandum in preparation, 2017.

${ }^{10}$ Cruz, J. R., Way, D. W., Shidner, J. D., Davis, J. L., Adams, D. S., and Kipp, D. M., "Reconstruction of the Mars Science Laboratory Parachute Performance," Journal of Spacecraft and Rockets, Vol. 51, No. 4, pp. 1185-1196, July-August 2014.

${ }^{11}$ Anon., JMP Statistics and Graphics Guide, Release 6, SAS Institute Inc., Cary, NC, 2005. 